\begin{abstract}
KONARIK, STEPHEN BRIAN. Trends in agricultural ammonia emissions and ammonium concentrations in precipitation over the Southeast and Midwest United States. (Under the direction of Dr. Viney P. Aneja and Dr. Dev Niyogi.)

Emissions from agricultural activities, both crop and animal, are known to contain gaseous ammonia $\left(\mathrm{NH}_{3}\right)$ which through chemical reaction in rainwater changes into ammonium ion $\left(\mathrm{NH}_{4}{ }^{+}\right)$. Using wet deposition data of ammonium from several National Atmospheric Deposition Program/National Trends Network (NADP/NTN) and Clean Air Status Trends Network (CASTNet) sites, as well as calculated ammonia emissions from North Carolina and the Southeast and Midwest regions of the United States, trends in ammonium concentrations in precipitation were analyzed for the period of 1983-2004. In addition, HYSPLIT back-trajectory model was used to determine that when ambient air in downwind sites arrived from the high ammonia emissions source region, ammonium concentrations in precipitation were enhanced. For the Southeast United States domain, analysis shows that $\mathrm{NH}_{4}{ }^{+}$concentrations generally increased with increasing $\mathrm{NH}_{3}$ emissions from within the same region. Similar analysis has been performed over the Midwest United States and compared to the results from the Southeast United States. Emissions from the Midwest are attributed to larger animals, including hogs and cattle, whereas the Southeast has a higher percentage of emissions coming from smaller livestock, such as chickens. In addition, the Midwest United States region has a much more uniform spatial distribution of emissions.
\end{abstract}

The conversion of ammonia gas $\left(\mathrm{NH}_{3}\right)$ into ammonium ion $\left(\mathrm{NH}_{4}{ }^{+}\right)$is a fundamental process that is of great environmental significance. Excessive amounts of $\mathrm{NH}_{4}{ }^{+}$can lead 
to acidification of soils and other pollution problems. An agricultural ammonia emissions inventory for the Midwest United States and Southeast United States was developed using data from the United States Department of Agriculture 2002 Census. This inventory indicates total annual ammonia emissions to be nearly the same over the two regions, with $1417 \times 10^{6} \mathrm{~kg} \mathrm{NH}_{3} / \mathrm{km}^{2} /$ year over the Southeastern United States and

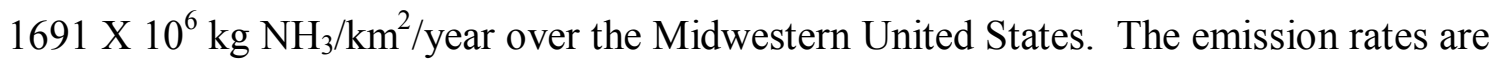
similar to those of model simulations from the Carnegie Mellon University Ammonia Model. Comparing these rates to the ammonium ion concentration and wet deposition obtained from the National Atmospheric Deposition Program (NADP) monitoring network reveals discrepancies from the results projected by the emissions inventory. The NADP network shows deposition rates of ammonium over the Southeast U.S. region at nearly twice those of the Midwest U.S. region. These contrasts have been explored and reasons for the differences are discussed.

The beginning of 1997 coincides with the implementation of a moratorium on new hog farms in the state of North Carolina. Results from the analysis in North Carolina indicate a lessening in the rate of increases in $\mathrm{NH}_{4}^{+}$concentration in precipitation since the moratorium went into effect. Sampson County, NC, saw stable ammonium ion concentrations from 1983-1989, an average rise of 9.5\% from 1989-1996, and an average increase of only $4 \%$ from 1997-2004. In analyzing the trends in $\mathrm{NO}_{\mathrm{x}}$, the effect of implementation of the Clean Air Act Amendments of 1990 is clearly seen in the precipitation chemistry as well. 


\title{
TRENDS IN AGRICULTURAL AMMONIA EMISSIONS AND AMMONIUM CONCENTRATIONS IN PRECIPITATION OVER THE SOUTHEAST AND MIDWEST UNITED STATES
}

\author{
by \\ STEPHEN BRIAN KONARIK
}

\author{
A thesis submitted to the Graduate Faculty of \\ North Carolina State University \\ in partial fulfillment of the \\ requirements for the Degree of \\ Master of Science
}

\section{ATMOSPHERIC SCIENCE}

Raleigh, North Carolina

2006

\section{APPROVED BY:}

\author{
Dr. S. Pal Arya
}

Committee Member
Dr. Dev Niyogi
Dr. Viney P. Aneja

Co-Chair of Advisory Committee

Co-Chair of Advisory Committee 


\section{BIOGRAPHY}

Stephen Brian Konarik was born in Taylor, TX on July 3, 1982. He graduated from Iowa State University in Ames, IA in 2004 with Bachelor of Science degrees in Meteorology and Environmental Studies. He completed a Master of Science in Atmospheric Science from North Carolina State University in Raleigh, NC in 2006, were he worked as a Research Assistant for the Air Quality Group at NC State. Following the completion of his Master's, Konarik will be working at URS Corporation in St. Louis, MO. 


\section{ACKNOWLEDGEMENTS}

I acknowledge support from the Cooperative State Research, Education, and Extension Service (CSREES), USDA National Research Initiative Competitive Grants Program, contract 2005-35112-15377. In addition, we would like to thank all members of the NC State University Air Quality Research Group for all of their assistance. Finally, I'd like to thank all of my family and friends for their support over the years. 


\section{TABLE OF CONTENTS}

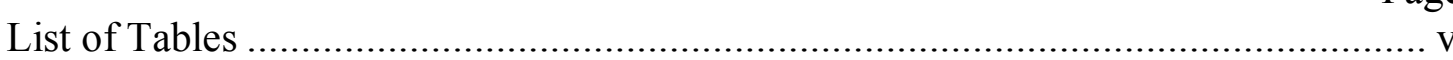

List of Figures ...................................................................................... vi

1. Trends in agricultural ammonia emissions and ammonium concentrations in precipitation over the Southeast and Midwest United States.......................... 1

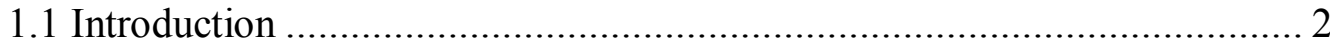

1.2 Methods

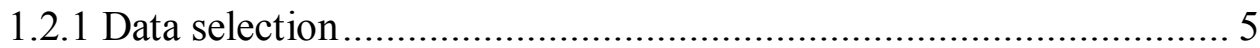

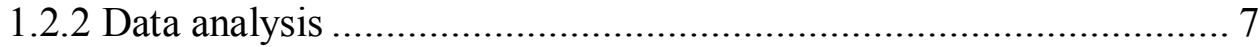

1.3 Results

1.3.1 Spatial distribution of $\mathrm{NH}_{3}$ emissions ..................................... 8

1.3.2 $\mathrm{NH}_{4}{ }^{+}$concentration analysis ............................................ 11

1.3.3 Effects of North Carolina's hog moratorium on ammonia

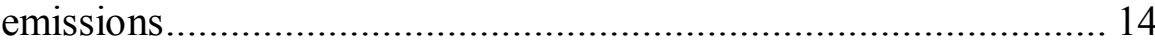

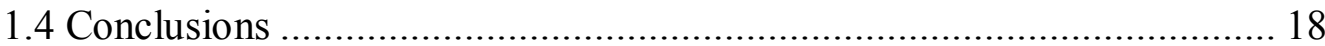

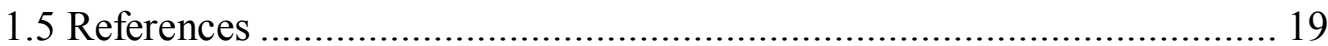

2. Analysis of local and regional effects of governmental environmental policy through observations in precipitation chemistry and local ambient

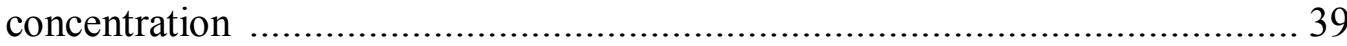

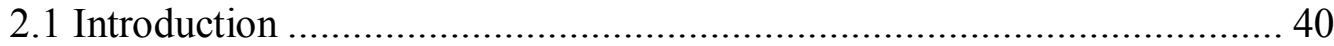

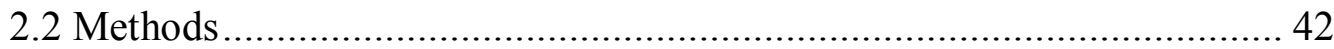

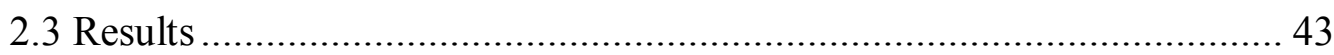

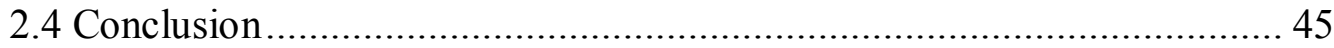

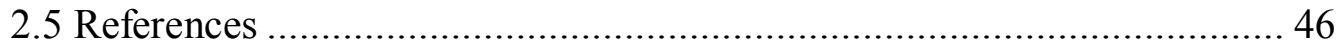

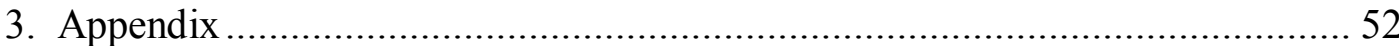

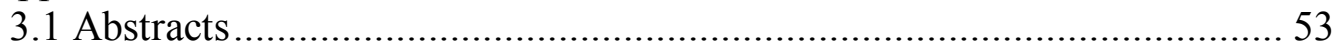




\section{LIST OF TABLES}

Table 1.1: CASTnet sites used in analysis of ammonia in ambient air.................... 22

Table 1.2: NADP sites used for analysis of $\mathrm{NH}_{4}{ }^{+}$concentration in wet deposition ... 23

Table 1.3: Emission factors used ............................................................... 25

Table 1.4: Emission factors used (fertilizer)................................................ 26

Table 1.5: Annual ammonia emissions flux from livestock and fertilizer sources, 2002 ........................................................................ 27

Table 1.6: Ten counties with highest annual agricultural emissions....................... 29

Table 1.7: Percentages of agricultural ammonia emissions deriving from specific sources in North Carolina.................................................................. 36

Table 1.8: Results of binomial proportion test for difference in source region air on high and low $\mathrm{NH}_{4}{ }^{+}$concentration days .......................................... 37 


\section{LIST OF FIGURES}

Page

Figure 1.1: HYSPLIT 'backwards' dispersion run from June 18, 2003 ................. 24

Figure 1.2: Spatial distribution of $\mathrm{NH}_{3}$ emissions $(\mathrm{kg} / \mathrm{sq}$. mile/ year) ..................... 28

Figure 1.3: Total ammonia emissions from specific agricultural sources, by state .... 30

Figure 1.4: Emissions from specific agricultural sources, by region ...................... 31

Figure 1.5: Standard deviation of ammonia emissions between counties in specific states............................................................................ 32

Figure 1.6: Ammonium ion concentrations from 3 Southeast sites .......................... 33

Figure 1.7: Ammonium ion concentrations from 3 Midwest sites ........................... 34

Figure 1.8: NADP maps for 2002 Ammonium ion concentration and ammonium ion wet deposition [Obtained from NADP/NTN (2005)] ....................... 35

Figure 1.9: $\mathrm{NH}_{4}{ }^{+}$wet deposition concentrations and trends over North Carolina, from 1989-2004 ........................................................................... 38

Figure 2.1: Annual $\mathrm{SO}_{2}$ and $\mathrm{NO}_{3}$ Concentrations, Beaufort, $\mathrm{NC}$, from 1994-2005

Figure 2.2: Annual $\mathrm{SO}_{2}$ and $\mathrm{NO}_{3}$ Concentrations, Candor, $\mathrm{NC}$, from 1990-2005

Figure 2.3: Annual $\mathrm{SO}_{2}$ and $\mathrm{NO}_{3}$ Concentrations, Cowetta, $\mathrm{NC}$ from 1988-2005

Figure 2.4: Annual $\mathrm{SO}_{2}$ and $\mathrm{NO}_{3}$ Concentrations, Cranberry, $\mathrm{NC}$ from 1989-2005 50

Figure 2.5: $\mathrm{NH}_{4}^{+}$wet deposition concentrations and trends over North Carolina, from 1989-2004 
1. Trends in agricultural ammonia emissions and ammonium concentrations in precipitation over the Southeast and Midwest United States 


\subsection{Introduction}

Agricultural-related ammonia $\left(\mathrm{NH}_{3}\right)$ emissions from crops and animals provide a means for the formation of ammonium ion $\left(\mathrm{NH}_{4}^{+}\right)$in the atmosphere, through the reactions with of acidic compounds and water (Pio 1992). These two compounds, $\mathrm{NH}_{\mathrm{x}}$ $\left(=\mathrm{NH}_{3}+\mathrm{NH}_{4}{ }^{+}\right)$, are beneficial to plant growth and act as nutrients at low concentrations, but at larger concentrations can cause acidification problems, eutrophication of water, decline in forest growth, and an increase in the formation of $\mathrm{PM}_{2.5}$ (Nelson 2000). Because of this, there is need to study the effects of the ammonia emissions from agricultural sources, including their concentration, distribution, and transport, so that a better understanding of effective means to control or reduce excess amounts of ammonia and ammonium deposition.

Globally, domestic animals are the largest source of atmospheric ammonia [32 $\times$ $10^{12}$ grams $\mathrm{NH}_{3}-\mathrm{N}$ (ammonia-nitrogen) per year], comprising approximately 40 percent of both the natural and anthropogenic emissions combined. Synthetic fertilizers and agricultural crops together contribute an additional $9 \times 10^{12}$ grams $\mathrm{NH}_{3}-\mathrm{N}$ per year $(12$ percent of total emissions). Manufacturing accounts for $2.2 \times 10^{12}$ grams $\mathrm{NH}_{3}-\mathrm{N}$ per year (3\% of total emissions (Aneja, 2001).

Ammonia $\left(\mathrm{NH}_{3}\right)$ released from near-surface sources (i.e. animal waste treatment lagoons, confinement houses, agricultural crops) into the atmosphere has a relatively short lifetime of 1-5 days (Aneja et al., 2001) and may deposit near the source through dry or wet deposition. However, ammonia can also participate in atmospheric chemical reactions (e.g. gas-to-particle conversion) once airborne, forming ammonium $\left(\mathrm{NH}_{4}{ }^{+}\right)$ 
salts, which tend to have longer atmospheric residence lifetimes ( 1-15 days) owing to a decrease in dry deposition velocity (Aneja et al., 2001) and therefore may be transported and deposited further downwind from the source.

At the Earth's surface, $\mathrm{NH}_{\mathrm{x}}\left(=\mathrm{NH}_{3}+\mathrm{NH}_{4}{ }^{+}\right)$has a range of well understood beneficial and detrimental consequences for humans and the environment. For example, nitrogen fertilizers have had a beneficial effect on agriculture globally by increasing crop yields. However, the high loading of reactive nitrogen has led to deleterious effects on the environment, such as acidification of soils, forest decline, decreased visibility from increased aerosol production, and elevated nitrogen (both ammonia and oxides of nitrogen $\left(\mathrm{NO}^{\mathrm{x}}\right)$ ) concentrations in ground and surface waters, possibly leading to enhanced eutrophication in downwind ecosystems (Asman, 1994; Aneja et al., 1998, 2001; Krupa, 2003; Baek and Aneja 2004). Thus, there is a need to study the ammonium deposition changes, spatial distribution, and transport of the ammonia emissions from agricultural sources in order to gain a better understanding of effective means to control or reduce excess amounts of ammonia and ammonium deposition.

The National Atmospheric Deposition Program/National Trends Network (NADP/NTN) was developed in 1978 in an effort to collect data on the chemistry and amount of precipitation for monitoring spatial and temporal long-term trends and is a cooperative effort between many different groups, including the State Agricultural Experiment Stations, U.S. Geological Survey, and the U.S. Department of Agriculture (NADP/NTN, 2004). In addition to other chemistry data, the NADP/NTN monitors $\mathrm{NH}_{4}{ }^{+}$concentration associated with precipitation, currently operating over 250 sites nationwide. 
Agriculture, forest, and range production practices are increasingly subject to U.S. state and federal regulations. Intended to protect air and water resources, numerous governmental regulations (local, regional, and national) have been set in order to curb the negative effects of excess $\mathrm{NH}_{\mathrm{x}}$ levels (Aneja et al., 2006). In particular, the emissions of ammonia nitrogen to the atmosphere remains largely unregulated. To facilitate the development of appropriate policies and regulations it is imperative that spatial distribution data on agricultural emissions of ammonia associated with specific geographic areas are accurate. Combining data from several different sources, this study attempts to provide generalizations in the trends of ammonia emissions, ammonia concentrations in the atmosphere, and ammonium concentrations in wet deposition. Comparisons were made between $\mathrm{NH}_{\mathrm{x}}$ characteristics in the Midwest United States and the Southeast United States. In addition, North Carolina was used as a case study to gauge the corollary effects of the 1997 swine production moratorium on ammonia emissions. This study attempts to show the effects of ammonia emission reductions as a result of hog population control, on localized deposition of ammonium in precipitation, since hog waste is a significant source of ammonium emissions (Baek 2004).

Also, in order to effectively implement proper regulations, it is necessary to quantitatively determine the effectiveness of monitoring programs such as NADP/NTN and theorize ways to improve there usefulness and/or alter them for use in agricultural air quality. 


\subsection{Methods}

\subsubsection{Data Selection}

For the purpose of comparison between the Midwest and Southeast United States, 16 states ( 8 from each region) were chosen as part of the study. The states of Alabama, Florida, Georgia, Kentucky, Mississippi, North Carolina, South Carolina, and Tennessee were defined as states in the Southeast United States. The Midwest United States was defined as the states of Illinois, Indiana, Iowa, Michigan, Minnesota, Missouri, Ohio, and Wisconsin.

In order to estimate ammonia emissions, the 2002 Census of Agriculture data was used. County level data of the population of cattle (both beef and dairy), horses, hogs (both sows and fattening pigs), sheep, broilers, chickens (including laying hens, young pullets, and more mature pullets), and turkeys were obtained. In addition, the acres of fertilized land and they type of fertilizer applied were also obtained.

For ammonium concentrations in the atmosphere associated with aerosols, data from 22 sites of the Clear Air Status and Trends Monitoring Network (CASTnet) was obtained. CASTnet is a network of rural sites that collect site-specific measurements of total deposition and is the source for dry acidic deposition (US EPA 2003). The sites measure weekly average ambient atmospheric concentrations of particulate $\mathrm{NH}_{4}^{+}$, as collected on a Teflon filter. The sites chosen have continuous data measurements from 1989-2004, so data was readily available for a long-term study such as this. The CASTnet sites used for the study are shown in Table 1.1 .

Next, data on $\mathrm{NH}_{4}{ }^{+}$concentrations associated with precipitation were obtained from the National Atmospheric Deposition Program/National Trends Network (NADP/NTN). 
From the data set of over 200 sites, 59 were chosen (30 from the Midwest United States and 29 from the Southeast United States). These sites have collected data weekly since 1978 (NADP 2005). The NADP sites used for this study are shown in Table 1.2.

The HYSPLIT (Hybrid Single-Particle LaGrangian Integrated Trajectory) model was used to determine whether or not atmospheric transport was playing a role in the periods of high $\mathrm{NH}_{4}{ }^{+}$concentrations over sites in North Carolina. HYSPLIT is a joint effort between NOAA and Australia's Bureau of Meteorology (NOAA 2005). It is able to compute air parcel simulations and dispersion and deposition simulations. For this study, HYSPLIT was used to perform a "backwards" dispersion model run for specified time periods at each site. The model assumed puff dispersion, where the puff expands and splits into several new puffs, each containing a portion of the pollutant mass (NOAA 2005). The dispersion shows the source region where the pollutant concentrations are coming from, and is therefore beneficial in determining if the swine facilities played a role in the ammonium concentration for that time period. For each model run, a 48 hour 'backwards' dispersion of deposition was performed from a source height of $100 \mathrm{~m}$. A sample output is shown in Figure 1.1.

The Carnegie Mellon University (CMU) Ammonia Emissions Model Version 3 (Davidson, 2004) was used to compare calculated emission rates with model estimates. The CMU model is a graphically interfaced software application with modifiable input files of emissions factors and activity levels designed to perform sensitivity analyses and inventory updates. In addition to livestock and fertilizer emissions, the CMU model provides emissions estimates for non-livestock animals (ie cats, dogs, wild animals), soils, and mobile and industrial sources. 
Additionally, 2002 Ammonium Ion Concentration in Precipitation and Wet Deposition maps produced by NADP/NTN (NADP, 2005) were used to compare and contrast both consistencies and inconsistencies between the calculated and modeled ammonia emission rates and its estimated wet deposition.

\subsubsection{Data Analysis}

The first goal of the study was to develop a spatial representation for agricultural ammonia emissions over both the Southeast United States and Midwest United States. To develop the emissions inventory, the data from the 2002 Census of Agriculture from the United States Department of Agriculture (USDA) was used. Since the data was county level, emissions were assumed to be constant throughout each individual county. To calculate the emissions total for each county, the animal population inventory numbers were multiple by an animal-specific emissions factor, in kilograms of ammonia per animal per year. These emissions factors have been obtained through experimentation and mass balance calculations, generally done in Europe, so there could be some error, since animal practices vary greatly between the two continents. In addition, the animal's specific diet can highly alter the $\mathrm{NH}_{3}$ emissions. Other factors, such as temperature, humidity, and waste handling, add to the uncertainties in the estimated emission factors. The final emission factors chosen to be used in the study were the same as those in the Aneja, et. al.(2003) study in which similar analysis was performed on 1997 Census of Agriculture data. The emission factors used are shown in Table 1.3 and Table 1.4. The total emissions per county were used to develop a spatial distribution across the two regions as well as to compare and contrast various characteristics of the distribution. Emissions and flux (i.e. normalized for area) were 
calculated and the data were further combined to provide statewide total emissions and flux estimates. Results are presented in Table 1.5.

CASTnet and NADP data was then used to develop statistical analyses of several locations to determine the correlations between $\mathrm{NH}_{3}$ emission, $\mathrm{NH}_{4}{ }^{+}$concentrations in ambient air, and $\mathrm{NH}_{4}{ }^{+}$concentrations in precipitation. In addition, sites in North Carolina were analyzed both before and after the installation of the hog moratorium to determine its effectiveness.

\subsection{Results}

\subsubsection{Spatial Distribution of $\mathrm{NH}_{3}$ emissions}

A map of the annual county-scale agricultural ammonia flux was developed.

Figure 1.2 depicts calculated and modeled livestock fluxes as well as overall agricultural flux (total of livestock and fertilizer) per county and the modeled total ammonia flux (agriculture plus all other sources combined). Emissions levels in these counties exceeded 10,000 kilograms per square kilometer per year. Various counties along a belt stretching from north-central Alabama across northern Georgia and South Carolina and to into southeastern South Carolina had emissions levels well in excess of $5,000 \mathrm{~kg} / \mathrm{km}^{2} / \mathrm{yr}$. Maximum values over the Midwest were significantly lower, with highest values over several counties in western Ohio and central and western Iowa. Table 1.6 lists the top 10 county in terms of annual agricultural emissions for both the Southeast United States and Midwest United States. Again, one can note the excessive values over southeastern North Carolina caused by the hog population and over portions of northern Alabama and Georgia, caused mainly due to the explosive growth of the broiler industry in those regions. The top 10 counties in the Midwest are characterized by significant beef cow 
populations across northwest Iowa, large poultry farms in Ohio, and hogs across Iowa and Indiana. Overall, when making the addition of North Dakota, South Dakota, and Nebraska to complete the entire agricultural region of the middle part of the United States, the Midwest had average ammonia emissions of $1691 \mathrm{~kg} / \mathrm{km}^{\wedge} 2 /$ year while the Southeast had emission levels of $1417 \mathrm{~kg} / \mathrm{km}^{\wedge} 2 /$ year.

Perhaps the most obvious distinction between the two regions in terms of agricultural ammonia emissions is the source of the emissions. Great variation in terms of the major type of livestock produced exists between the two regions. Figure 1.3a and $1.3 \mathrm{~b}$ show the average $\mathrm{NH}_{3}$ emissions deriving from specific agricultural sources in the Southeast and Midwest, respectively.

The figures indicate that high ammonia emissions totals over the Southeast United States in general come from broilers, but with the distinct exceptions of North Carolina in terms of hog emission as well as the dairy and beef cow industries in Tennessee. In contrast, the Midwest United States has its high ammonia emissions totals deriving mainly from the hog industry, especially over Indiana, Iowa, and Minnesota. Cows, in particular beef, play a major role in agricultural ammonia emissions over Wisconsin and Missouri.

In terms of the regions as a whole, the Midwest had roughly $40 \%$ of its total agricultural emissions stemming from hogs, with $8 \%$ and $12 \%$ coming from beef and dairy cows, respectively. Fertilizer accounted for $14 \%$ of the emissions, whereas turkeys, chickens, and broilers combined to contribute 15\%. In the Southeast, an overwhelming $43 \%$ of agricultural emissions of $\mathrm{NH}_{3}$ came from broilers, with $11 \%$ deriving from fertilizer, and $16 \%$ stemming from the hog industry. Beef and dairy cows made up $12 \%$ 
and $9 \%$ respectively, and chickens and turkeys contributed $4 \%$ each. A previous study from five years early over the same Southeast region reported 33\% broiler contribution, $28 \%$ beef cattle, $12 \%$ hog and $12 \%$ fertilizer (Aneja, et al., 2003). This indicates that the broiler industry is rapidly growing, while the beef industry is declining over the region as indicated by the Census of Agriculture Data (NADP, 2005). The details of the relative contribution of each specific source to the total emissions for the region are shown in Figure 1.4.

In comparing spatial distributions of agricultural ammonia emissions between the two regions, the Southeast has a much greater deviation in emissions locally. One of several explanations of this is that the Southeast United States is characterized by a more complex terrain, which mountains, swamps, and forests all separating localized areas of intensive agriculture. In addition, the denser population of the Southeast again provides a more localized nature to agricultural areas. The Midwest, in contrast, is characterized by flat or gently rolling open plains, and with a much less dense population, there is a great uniformity to the intensity of agriculture in the region, allowing for more extensive, yet relatively moderate levels of agricultural ammonia emissions. Another possible explanation is the aforementioned fact that livestock in the Midwest is characterized by larger animals (which make up about $64 \%$ of the emissions, as opposed to $37 \%$ in the Southeast), which cannot be as densely populated as the smaller animals of the Southeast. Figure 1.5 shows the average standard deviation between emission totals in counties of the states included in the study. It is clear that the variation in emissions is much greater in the Southeast than in the Midwest, with the highest variation in the states with the 
highest overall emissions totals as well as those with the highest percentages of small animal inventories.

\subsection{2. $\mathrm{NH}_{4}{ }^{+}$concentration analysis}

In order to analyze the relationship between $\mathrm{NH}_{3}$ emissions at the county level and $\mathrm{NH}_{4}{ }^{+}$concentrations in both ambient air, comparisons were made between the average levels of NH4+ concentrations from the NADP and CASTnet sites and the total agricultural ammonia emissions calculated from the annual emissions totals. The correlation between the two gave an R-squared value of 0.475 for both regions combined, with 0.384 being the R-squared value for the Southeast and 0.531 for the Midwest. Hence, there is significant relationship between a county's ammonia emissions and the concentration of $\mathrm{NH}_{4}{ }^{+}$in the atmosphere and in precipitation. The Southeast's correlation was lower due to the same reasons as stated above, i.e., higher variability in $\mathrm{NH}_{3}$ emissions. Specifically, the more varied terrain and higher variations between neighboring counties would allow for a county with low emissions next to a high emissions county to possess high $\mathrm{NH}_{4}{ }^{+}$values due to its proximity to the high $\mathrm{NH}_{3}$ emissions nearby. With the more uniform emissions in the Midwest, there is less of a difference between neighboring counties, and thus less of a difference in concentrations of $\mathrm{NH}_{4}{ }^{+}$if $\mathrm{NH}_{3}$ sources come from a neighboring county instead of from within. Figure 1.6 shows several examples from the Southeast United States. The figure indicates fourweek averaged ammonium ion concentrations in both ambient air (from the CASTnet site) and precipitation (from the NADP site) as well as the long term trend from 19892004. These examples show counties that contained both CASTnet and NADP sites. Figure 1.6a shows Pike County, GA. Pike County is located in west-central Georgia, just 
to the south-southwest of metropolitan Atlanta. It is to the south and east of the highest agricultural ammonia emissions counties in the United States, while 2,005 kg/sq. km/year of ammonia was calculated to be emitted from agricultural sources within the county annually, mostly from the broiler population. For this study, Pike County was considered a moderate-emissions county. The terrain of the county is generally rolling farmland. Average daily concentrations of ammonium in precipitation have slowly risen from about $0.30 \mathrm{mg} / \mathrm{L}$ over the past 5 years or so to $0.35 \mathrm{mg} / 1$, whereas ammonium ion concentrations in ambient air have decreased from a mean of $1.6 \mathrm{ug} / \mathrm{m}^{3}$ during the same time frame to $1.3 \mathrm{ug} / \mathrm{m}^{3}$. Figure $1.6 \mathrm{~b}$ shows DeKalb County, AL. DeKalb County is in the northeastern tip of Alabama, in the heart of the extreme broiler ammonia emissions region, with DeKalb itself having agricultural ammonia emissions of about 8,102 $\mathrm{kg} / \mathrm{sq} . \mathrm{km} /$ year. The county is also characterized by rolling farmland. Ammonium ion concentrations over the county in ambient air remained generally constant at $2.5 \mathrm{ug} / \mathrm{m}^{3}$, whereas the average concentration in precipitation rose from $0.3 \mathrm{mg} / \mathrm{L}$. Figure $1.6 \mathrm{c}$ shows Anderson County, TN. Anderson County, Tennessee is located on the western side of the Knoxville area, and is characterized by mixed agricultural use to the north of the large high-emissions areas in Georgia and Alabama. This county, considered low agricultural-related ammonia emissions, again, has rolling farmland, with an annual emissions total of $239 \mathrm{~kg} / \mathrm{sq}$. km/year. Both concentrations of ammonium ion in ambient air and in precipitation dropped, from $2 \mathrm{ug} / \mathrm{m}^{3}$ and $0.33 \mathrm{mg} / \mathrm{L}$ to $1.5 \mathrm{ug} / \mathrm{m}^{3}$ and $0.28 \mathrm{mg} / \mathrm{L}$ respectively.

Figure 1.7 shows the data from 3 sites over the Midwest United States. Figure 1.7a shows data from Butler County, $\mathrm{OH}$, considered a moderate agricultural ammonia 
emissions county for the Midwest with $406 \mathrm{~kg} / \mathrm{sq}$. km/year emissions. Butler County is located in southwestern Ohio, on the northwest side of Cincinnati. There are counties to the north that have significantly higher levels of hogs, which is also the key constituent of agricultural activities in this county, characterized by rolling farmland. Ammonium ion concentrations in ambient air have been dropping, from $2 \mathrm{ug} / \mathrm{m}^{3}$, as have concentrations in precipitation, dropping from $0.4 \mathrm{mg} / \mathrm{L}$. Figure $1.7 \mathrm{~b}$ shows Champaign County, IL, located in east-central Illinois, in a relatively low emissions area far to the east and southeast of the major hog and cow agricultural centers of the Midwest. The site is characterized by flat farmland, and county-level agricultural ammonia emissions are at a mere $155 \mathrm{~kg} / \mathrm{sq}$. km/year. Surprisingly, $\mathrm{NH}_{4}{ }^{+}$concentrations in precipitation are rising from $0.5 \mathrm{mg} / \mathrm{L}$ to $0.55 \mathrm{mg} / \mathrm{L}$, whereas ambient air concentrations of $\mathrm{NH}_{4}{ }^{+}$have been dropping. Finally, figure 1.7c shows Knox County, IN, which is considered the high emissions example for the Midwest. Knox County is located in southwestern Indiana, and is part of a cluster of counties whose rolling farmland is dotted with hog facilities. The annual agricultural related ammonia emission from the county is estimated at 1,436 $\mathrm{kg} / \mathrm{sq}$. $\mathrm{km} /$ year. The levels of ammonium ion concentration in ambient air, has been dropping from a mean of about $2 \mathrm{ug} / \mathrm{m}^{3}$, whereas the mean in precipitation has slightly dropped from around $0.42 \mathrm{mg} / 1$ to $0.38 \mathrm{mg} / \mathrm{l}$.

In comparing the trends between the sites and others used in the studies, it is evident that agricultural emissions are higher in certain counties over the Southeast, but are overall higher in the Midwest. Also, concentrations of $\mathrm{NH}_{4}{ }^{+}$in precipitation is higher in the Midwest. Ambient air concentrations of ammonia in the Midwest seem to be much more dependent on local emissions, with high-level emission areas having higher $\mathrm{NH}_{4}{ }^{+}$ 
concentrations in ambient air. An explanation for the enhanced $\mathrm{NH}_{4}{ }^{+}$in precipitation over the Midwest may have to do with the fact that most moisture from the Midwest arrives from the south, which could mean a significant amount of agriculturally emitted ammonia from the Southeast United States is being transported to the Midwest, where it is being released through precipitation.

Figure 1.8 shows NADP maps for the annual 2002 ammonium ion concentration and ammonium ion wet deposition (NADP/NTN, 2004) Comparing these maps to both the calculated and modeled ammonia emissions in Figure 1.1, there is a significant inconsistency between the emissions and deposition. The Midwest and Southeast United States have similar calculated and modeled emissions; however, the Midwest has much higher ammonium deposition values (deposition is normalized for precipitation amount). The ammonium deposition values indicate that on average, the Midwest United States has double the amount of deposition, $4.0 \mathrm{~kg} / \mathrm{Ha}$ to $2.0 \mathrm{~kg} / \mathrm{Ha}$, whereas Figure 1.1 as well as Table 1.3 indicate that the emissions levels in the Midwest are only about $20 \%$ higher. This discrepancy appears particularly distinct in Iowa and Minnesota, where emissions values average around $2000 \mathrm{~kg} / \mathrm{km}^{2} \mathrm{yr}^{-1}$ but ammonium ion concentrations averages exceed $0.6 \mathrm{mg} / \mathrm{L}$ with deposition values of $4.0 \mathrm{~kg} / \mathrm{Ha}$. In contract, North Carolina, with emissions values of $2,700 \mathrm{~kg} \mathrm{~km}^{-2} \mathrm{yr}^{-1}$ has ammonium ion concentrations of approximately $0.3 \mathrm{mgL}^{-1}$ and deposition values of $2.5 \mathrm{~kg} / \mathrm{Ha}$.

\subsubsection{Effects of North Carolina's Hog Moratorium on Ammonia emissions}

In Early 1997, a moratorium was put into effect by the North Carolina General Assembly, to cap the number and size of hog-confinement facilities in the state to that existing at the time of enactment. The General Assembly was reacting to the hog 
operations detrimental effect on the environment, in terms of water pollution, odor, disease, and air pollution. The moratorium banned the creation of any new confinement facilities in the state, effectively eliminating the growth of the swine population in the state. One of the key air pollution problems associated with the hog facilities are the ammonia emissions. The facilities, particularly in the southeastern part of North Carolina (see Figure 1.2), have been allegedly responsible for enhanced ammonium ion concentrations throughout eastern parts of the state. Given the effect the moratorium has had on stopping the rapid growth of the industry in North Carolina, it is of interest to examine whether there has been a reduction, or at least halting of the increase, in ammonium ion concentrations in the area relative to the years before the moratorium was in place. This study looked at pre-1997 trends in ammonium ion concentrations and compared them to post-moratorium trends.

Table 1.7 shows the percentages of total annual emissions $\mathrm{NH}_{3}$ from agricultural sources that derive each specific source, using the emissions calculations from 2002 Agricultural Census data. If compared with data from Figure 1.4, it is clear that emissions from hogs play much more of a major role in North Carolina than in the rest of the southeast, making up near a half of all agricultural-related ammonia emissions in the state.

In order to take a look at how this ammonia emissions source region affects other areas of the state's ammonium ion concentration, analysis was performed using weekly NADP data couple with HYSPLIT back-trajectory runs. A comparison was made between the $90^{\text {th }}$ percentile and the $10^{\text {th }}$ percentile for concentrations of ammonium ions in precipitation at each of two NADP sites. HYSPLIT model back-trajectories were 
performed to determine if those percentile distributions of ammonium concentrations corresponded with air masses transiting the source region. A statistical F-test analysis was done, assuming a large sample size, for NADP sites NC41 (Wake in eastern central North Carolina) and NC34 (Rowan in western central North Carolina) using Microsoft Excel (Table 1.8). The analysis identified the number of days with air at the site derived from the source region with $\mathrm{NH}_{4}{ }^{+}$in precipitation in the $90^{\text {th }}$ or $10^{\text {th }}$ percentile. The source region was defined as the area $50 \mathrm{~km}$ in radius from a center point of $35.1 \mathrm{~N}$, $77.9 \mathrm{~W}$, and is representative of the area with the highest concentration of hog facilities. Any day on which over $50 \%$ of the air at the site that had passed over the source region within the 48 hours leading up to the sample time and a concentration of $\mathrm{NH}_{4}{ }^{+}$in the minimum/peak category was considered a 'yes' day. The sample was considered a 'no' day if it didn't meet the preceding criteria. The test indicated a statistically greater number of days in the $90^{\text {th }}$ percentile for air transiting the source region for Wake County (p-values $<0.05$ ). The site in Rowan County, further to the west, did not show a statististical relationship between ammonia in precipitation and air transiting the source region. Theses results indicate that $\mathrm{NH}_{4}{ }^{+}$concentrations over eastern North Carolina, at least 80 miles from the source region, are significantly dependant on the emissions from hog facilities.

The concentrations of ammonium ions in precipitation were analyzed from seven NADP sites in North Carolina from 1989-1996 and again from 1997-2004 (Figure 1.8.) Four of the sites are considered low agricultural emissions locations. NC25 is located in Macon County, in the far western part of the state. Although highly vegetated and mountainous, it is located close to the extreme agricultural ammonia emissions area of 
northern Georgia. Its annual estimate of agricultural related ammonia emissions is 59.0 kilograms per square kilometer. Also in the west, but north of NC 25 in a higher terrain, is NC45, in Yancey County (elevation 1,987 m). NC45 has an annual estimated ammonia emissions rate of $113 . \mathrm{kg} / \mathrm{sq} . \mathrm{km}$. Further to the east, sandwiched between the Greensboro-Winston-Salem and Charlotte metropolitan areas lies Rowan County (NC34), consisting of blossoming suburbs growing between agricultural regions. This area still has relatively low areas of emissions, with 398 kilograms per square kilometer of ammonia emissions related to agricultural activities annually. The final low-emissions site was Wake County, where the capital of Raleigh is located. NC41, in Wake County, is less than 80 miles to the north-northwest of the extremely high swine population region, but despite this, the county's estimated annual emissions of agricultural related ammonia is $31 \mathrm{~kg} / \mathrm{sq}$. km. The three high emissions sites, NC03, NC35, and NC36, are located in the eastern half of the state. NC36 is located in Scotland County, in the southcentral part of the state, west of the highest ammonia-emitting county, but itself emitting $1408 \mathrm{~kg} / \mathrm{sq}$. kilometer of ammonia annually. NC03, in Bertie County, in the low-lying northeastern section of the state, has emission estimates of $2502 . \mathrm{kg} / \mathrm{sq} . \mathrm{km}$ annually, and with mean wind (southwesterly) transporting air directly from the source. Finally, Sampson County, in the heart of the hog production region in North Carolina in the southeastern part of the state, has an annual emissions rate of agricultural related ammonia of 19,560 kilograms $\mathrm{NH}_{3}$ per square kilometer annually, making it the highest emitter in the state.

Figure 1.9 shows the weekly ammonium ion concentrations (a 4-week rolling average) in wet deposition at each of the seven sites. As expected, Sampson County 
(NC35) has higher wet deposition values over both periods than the other high-emission sites. However, Wake County (NC41) and Rowan County (NC34) have generally high average wet deposition values than the other two high emission sites. For Wake County this feature can easily be explained by its proximity to high emissions areas, but for $\mathrm{NC} 34$, the reason for the high levels is more uncertain. As for the trends, the hog moratorium has clearly cut down on the rate of increase of $\mathrm{NH}_{4}{ }^{+}$concentrations in precipitation over Sampson County (NC35), whose rate of increase over the 8 year period before the moratorium was $9 \%$, and since the moratorium is $4 \%$. The other sites show much less of an effect. Bertie County (NC03) and Scotland County (NC36) have steady but slow increase in $\mathrm{NH}_{4}{ }^{+}$concentration in precipitation from 1989-2004. For the lower emission sites, Wake County (NC41) saw a significant decrease in concentrations before the moratorium took into effect, with steady levels since then. The urbanization of Wake County over the last 15 years may be a reason for the interesting trends, and this could also explain the enhanced levels over suburban Wake County (NC41). The other two low-emission sites, Macon County (NC25) and Rowan County (NC34), have been generally stable. It is worth noting that $\mathrm{NC45}$ has had a slight increasing trend before the moratorium, with a slight decreasing trend afterwards, whereas NC35 has had the opposite trends.

\subsection{Conclusions}

Calculating ammonia emissions totals using animal inventories and emission factors can provide a useful means of depicting the spatial scale, distribution, and characteristics of agricultural related ammonia emissions at the county level. Improvements are needed in the accuracy of the emission factors on animals in the 
United States as well as diet specific emission factors, which will greatly enhance the accuracy of these estimates. The estimates provide a means of correlating ammonia emissions to ammonium ion concentrations, both in ambient air and in precipitation. A reasonable positive correlation seems to exist, but future work is needed to add in other factors which may affect the transport, deposition, and chemical transformation of both ammonia and ammonium ion, particular with regards to meteorological parameters and non-agricultural related emissions. The atmospheric chemical composition is being altered in the agricultural environments, owing in large part, to intensively managed crop and animal agriculture. The National Atmospheric Deposition Program network of measurements has served the nation well largely for monitoring the changes associated with energy and urban issues. However, a new paradigm needs to be evolved for agricultural needs and how it impacts air quality.

The effects of the hog moratorium in North Carolina, which undoubtedly curbed the increasing rates of agricultural ammonia emissions in addition to its intended effect of stopping the growth of the hog industry, aren't seen clearly in merely analyzing the trends of ammonium ion concentrations in precipitation over the last seven years, with the exception of areas immediately in the vicinity of the high hog facility density. There are a number of reasons that could be postulated as to why the level of $\mathrm{NH}_{4}{ }^{+}$has not leveled off in the last 7 years since the installation of the moratorium, but as with the $\mathrm{NH}_{3}$ emissions, meteorological parameters and industrial activity would need to be taken into account before a more clear understanding of the effect of the moratorium on ammonia emissions is obtained. 


\subsection{REFERENCES}

Aneja, V. P., G. C. Murray, and J. Southerland. 1998. Atmospheric nitrogen compounds: Emissions, transport, transformation, deposition and assessment, EM, 22-25.

Aneja, V.P., P.A. Roelle, G.C. Murray, J. Southerland, J.W. Erisman, D. Fowler, W.A.H. Asman, and N. Patni. 2001. Atmopheric nitrogen compounds II: emissions, transport, transformation, deposition, and assessment. Atmospheric Environment 35: 1903-1911.

Aneja, V.P., D.R. Nelson, P.A. Roelle, J.T. Walker, and W. Battye. 2003. Agricultural ammonia emissions and ammonium concentrations associated with aerosols and precipitation in the southeast United States. J. Geophys. Res., 108(D4), 4152.

Aneja, V.P., W.H. Schlesinger, D. Niyogi, G. Jennings, W. Gilliam, R.E. Knighton, C.S. Duke, J. Blunden, and S. Krishnan, Emerging National Research Needs for Agricultural Air Quality. 2006. EOS, 87(3), 25-29.

Asman, W. A. 1994. Emission and deposition of ammonia and ammonium, Nova Acta Leopold 70: 263- 297.

Baek, B.H. and V.P. Aneja. 2004. Measurement and analysis of the relationship between ammonia, acid gas, and fine particulates in eastern North Carolina, J. Air Waste Manage. Assoc., 54(5), 623-633.

Chemical speciation of PM2.5 in urban and rural areas. 2003. National Air Quality and Emissions Trends Report.

Clean Air Status and Trends Network (CASTNet), 2003 Annual Report. 2003. (Available as www.epa.gov/acidrain/castnet/annual03/annual03.html).

Davidson, Cliff. 2004. Carnegie Mellon University Ammonia Model, CMU Ammonia Emission Inventory for the Continental United States. (Available as http://www.cmu.edu/ammonia/).

Elminir, H.K. 2005. Dependence of urban pollutants on meteorology, Sci. Total Environ., doi:10.1016/j.scitotenv.2005.01.043.

Hoppin, J.A., D.M. Umbach, S.J. London, M.C. Alavanja, and D.P. Sandler. 2003. Animal production and wheeze in the Agricultural Health Study: interactions with atopy, asthma, and smoking. Occup Environ Med. Aug;60(8):e3.

Krupa, S.V. 2003. Effects of atmospheric ammonia $\left(\mathrm{NH}_{3}\right)$ on terrestrial vegetation: Review. Environmental Pollution 124: 179-221. 
Lo, A.K., L. Zhang, and H. Sievering. 1999. The effect of humidity and state of water surfaces on deposition of aerosol particles onto a water surface, Atmos. Environ., 33(28), 4727-4737, doi:10.1016/S1352-2310(99)00202-2.

National Atmospheric Deposition Program (NRSP-3)/National Trends Network (NADP/NTN). August, 2005. NADP/NTN Coord. Off., Illinois State Water Survey, 2204 Griffith Drive, Champaign, IL, 2005 (Available as nadp.sws.uiuc.edu/).

National Oceanic and Atmospheric Admininstration (NOAA). 2005. Air Resources Laboratory READY. HYSPLIT Model. (Available at:

http://www.arl.noaa.gov/ready/hysplit4.html).

Nelson, D. R. 2000. Analysis of ammonia emissions from agriculture and ammonium concentrations in the southeastern United States, M.S. thesis, Dept. of Mar., Earth and Atmos. Sci., North Carolina State Univ., Raleigh, N.C.

Pio, C.A., T.V. Nunes, and R.M. Leal. 1992. Kinetic and thermodynamic behaviour of volatile ammonium compounds in industrial and marine atmospheres, Atmos. Environ., 26(3), 505-512.

Rhome, J.R., D.S. Niyogi, and S. Raman. 2001. Assessing seasonal transport and deposition of agricultural emissions in eastern North Carolina, USA. Pure App. Geo, 160, $117-141$.

USDA (United States Department of Agriculture). 2005. 2002 Census of Agriculture Volume 1: Part 1, Chapter 2, Nat. Agric. Stat. Serv., Washington, D.C.

U.S. Environmental Protection Agency (EPA). 2003. Clean Air Status and Trends Network (CASTNet) Deposition Summary Report 1996-2003). (Available at www.epa.gov/castnet/).

Walker, J.T., V.P. Aneja, and D.A. Dickey. 2000. Atmospheric transport and wet deposition of ammonium in North Carolina, Atmos. Environ., 34(20), 3407-3418, doi:10.1016/S1352/S1352-2310(99)00400-9.

Walker, J.T., D. Nelson, and V.P. Aneja. 2000. Trends in ammonium concentrations in precipitation and atmospheric ammonia emissions at a Coastal Plain site in North Carolina, USA, Enivon. Sci. Technol., 34, 3527-3534. 
Table 1.1: CASTnet Sites Used in Analysis of Ammonia in Ambient Air

\begin{tabular}{|c|c|c|c|c|c|c|c|}
\hline State & Site_id & County & Latitude & Longitude & Land Use & Terrain & $\begin{array}{c}\text { Elevation } \\
\text { (m) }\end{array}$ \\
\hline \multicolumn{8}{|c|}{ SOUTHEAST } \\
\hline $\mathrm{AL}$ & $\underline{\text { SND152 }}$ & DeKalb & 34.2888 & -85.9698 & Agriculture & Rolling & 352 \\
\hline $\mathrm{FL}$ & $\underline{\text { SUM156 }}$ & Gadsden & 30.1103 & -84.9903 & Forest & Flat & 14 \\
\hline GA & GAS153 & Pike & 33.1787 & -84.4052 & Agriculture & Rolling & 270 \\
\hline $\mathrm{KY}$ & $\underline{\text { CKT136 }}$ & Rowan & 37.9214 & -83.0662 & Agriculture & Rolling & 455 \\
\hline KY & MCK131 & Washington & 37.7046 & -85.0485 & Agriculture & Rolling & 353 \\
\hline MS & $\underline{\text { CVL151 }}$ & Yalobusha & 34.0026 & -89.7989 & Forest & Rolling & 134 \\
\hline $\mathrm{NC}$ & $\underline{\text { CND125 }}$ & Rowan & 35.2632 & -79.8365 & Forest & Rolling & 198 \\
\hline $\mathrm{NC}$ & cow 137 & Macon & 35.0608 & -83.4305 & Forest & Complex & 686 \\
\hline $\mathrm{NC}$ & PNF126 & Yancey & 36.1058 & -82.0454 & Forest & Mountainous & 1219 \\
\hline $\mathrm{TN}$ & SPD111 & Anderson & 36.47 & -83.8268 & Agriculture & Rolling & 361 \\
\hline \multicolumn{8}{|c|}{ MIDWEST } \\
\hline $\mathrm{Ml}$ & ANA115 & Washtenaw & 42.4165 & -83.902 & Forest & Flat & 267 \\
\hline $\mathrm{Ml}$ & $\underline{\mathrm{HOX} 148}$ & Wexford & 44.1809 & -85.739 & Forest & Flat & 305 \\
\hline $\mathrm{MI}$ & $\underline{\text { UVL124 }}$ & Tuscola & 43.6138 & -83.3591 & Agriculture & Flat & 201 \\
\hline MN & VOY413 & St. Louis & 48.4128 & -92.8292 & Forest & Rolling & 429 \\
\hline $\mathrm{OH}$ & DCP114 & Fayette & 39.6359 & -83.2605 & Agriculture & Rolling & 267 \\
\hline $\mathrm{OH}$ & $\underline{\text { LYK123 }}$ & Crawford & 40.9173 & -82.9982 & Agriculture & Flat & 303 \\
\hline $\mathrm{OH}$ & OXF122 & Butler & 39.5327 & -84.7286 & Agriculture & Rolling & 284 \\
\hline $\mathrm{OH}$ & QAK172 & Noble & 39.9428 & -81.3373 & Agriculture & Rolling & 372 \\
\hline WI & $\underline{\text { PRK134 }}$ & Taylor & 45.2066 & -90.5969 & Agriculture & Rolling & 472 \\
\hline IL & $\underline{\mathrm{ALH} 157}$ & Madison & 38.869 & -89.6228 & Agriculture & Flat & 164 \\
\hline IL & BVL130 & Champaign & 40.0519 & -88.3724 & Agriculture & Flat & 212 \\
\hline IN & VIN140 & Knox & 38.7408 & -87.4853 & Agriculture & Rolling & 134 \\
\hline
\end{tabular}


Table 1.2: NADP Sites used for Analysis of NH4+ concentration in Wet Deposition

\begin{tabular}{|c|c|c|c|c|c|c|c|c|c|}
\hline $\begin{array}{l}\text { Site } \\
\text { _id }\end{array}$ & County & Latitude & Longitude & $\begin{array}{c}\text { Elev } \\
\text { atio } \\
n \\
(m)\end{array}$ & $\begin{array}{l}\text { Site } \\
\text { id }\end{array}$ & County & $\begin{array}{c}\text { Latitud } \\
\mathbf{e}\end{array}$ & Longitude & $\begin{array}{c}\text { Elev } \\
\text { atio } \\
n \\
(\mathrm{~m})\end{array}$ \\
\hline \multicolumn{5}{|c|}{ SOUTHEAST } & \multicolumn{5}{|c|}{ MIDWEST } \\
\hline$\underline{\mathrm{AL} 10}$ & Dallas & 32.458 & -87.2422 & 58 & $\underline{\mathrm{AA08}}$ & Clayton & 42.91 & -91.47 & 229 \\
\hline AL99 & DeKalb & 34.288 & -85.9699 & 349 & IA23 & Lucas & 40.963 & -93.3925 & 320 \\
\hline FL03 & Bradford & 29.974 & -82.1981 & 44 & IL11 & Champaig & 40.053 & -88.3719 & 212 \\
\hline$\underline{\text { FL05 }}$ & Citrus & 28.749 & -82.5542 & 3 & $\underline{\mathrm{L} 18}$ & DeKalb & 41.841 & -88.8511 & 265 \\
\hline FL11 & Dade & 25.39 & -80.68 & 2 & $\underline{\text { LL46 }}$ & Madison & 38.869 & -89.6215 & 164 \\
\hline$\underline{\text { FL14 }}$ & Gadsen & 30.548 & -80.6008 & 60 & $\underline{\mathrm{L} 78}$ & Warren & 40.933 & -90.7231 & 229 \\
\hline$\underline{F L 41}$ & Sarasota & 27.38 & -82.2839 & 25 & IN20 & Huntington & 40.84 & -85.4639 & 244 \\
\hline FL99 & Brevard & 28.542 & -80.6444 & 2 & IN22 & Knox & 38.741 & -87.4855 & 134 \\
\hline$\underline{\text { GA09 }}$ & Charlton & 30.604 & -82.1286 & 47 & $\underline{\mathrm{NN} 34}$ & Porter & 41.633 & -87.0878 & 208 \\
\hline$\underline{\mathrm{GA} 20}$ & Evans & 32.141 & -81.9714 & 62 & IN41 & Tippacano & 40.475 & -86.992 & 215 \\
\hline GA41 & Pike & 33.177 & -84.4061 & 270 & $\mathrm{Ml} 26$ & Kalamazo & 42.401 & -85.3928 & 288 \\
\hline GA99 & Tift & 31.518 & -3.5483 & 107 & MI51 & Tuscola & 43.613 & -83.3581 & 201 \\
\hline $\mathrm{KYO3}$ & Washingto & 37.704 & -85.0489 & 293 & MI52 & Washtena & 42.416 & -83.9019 & 267 \\
\hline$\underline{\mathrm{KY} 22}$ & Letcher & 37.077 & -82.9936 & 335 & $\underline{\mathrm{Ml} 53}$ & Wexford & 44.224 & -85.8186 & 292 \\
\hline$\underline{\mathrm{KY}} 35$ & Rowan & 38.118 & -83.1183 & 204 & MN01 & Anoka & 45.413 & -93.2125 & 280 \\
\hline$\underline{\text { MS10 }}$ & Hinds & 32.306 & -90.3069 & 86 & MN23 & Morrison & 46.249 & -94.4972 & 410 \\
\hline MS19 & Newton & 32.326 & -89.2086 & 115 & MN27 & Redwood & 44.237 & -95.3006 & 343 \\
\hline$\underline{\mathrm{MS} 30}$ & Yalobusha & 34.002 & -89.7993 & 134 & MN32 & St. Louis & 48.413 & -82.8298 & 429 \\
\hline$\underline{\mathrm{NCO} 3}$ & Bertie & 36.132 & -77.1708 & 22 & $\underline{\mathrm{MO} 03}$ & Boone & 38.754 & -92.1989 & 239 \\
\hline $\mathrm{NC25}$ & Macon & 35.060 & -83.4305 & 686 & $\mathrm{MO} 05$ & Butler & 36.411 & -90.3186 & 154 \\
\hline$\underline{\mathrm{NC} 34}$ & Rowan & 35.697 & -80.6225 & 219 & $\mathrm{MO43}$ & St. Louis & 38.521 & -90.5541 & 174 \\
\hline$\underline{\mathrm{NC} 35}$ & Sampson & 35.025 & -78.2783 & 41 & $\mathrm{OH} 09$ & Butler & 39.531 & -84.7242 & 284 \\
\hline$\underline{\mathrm{NC} 36}$ & Scotland & 34.970 & -79.5281 & 132 & $\underline{\mathrm{OH} 15}$ & Crawford & 40.917 & -82.9981 & 303 \\
\hline$\underline{\mathrm{NC} 41}$ & Wake & 35.728 & -78.6802 & 120 & $\underline{\mathrm{OH}} 49$ & Noble & 39.793 & -81.5311 & 276 \\
\hline NC45 & Yancey & 35.735 & -82.2861 & 1987 & $\underline{\mathrm{OH} 54}$ & Pickaway & 39.636 & -83.26 & 267 \\
\hline$\underline{\mathrm{sC} 06}$ & Claredon & 33.539 & -80.435 & 24 & WI28 & Portage & 44.665 & -89.6522 & 338 \\
\hline$\underline{\mathrm{TNOO}}$ & Anderson & 35.961 & -84.2872 & 341 & $\underline{W} 135$ & Taylor & 45.206 & -90.5978 & 472 \\
\hline$\underline{\text { TN11 }}$ & Sevier & 35.664 & -83.5903 & 640 & $\underline{W} 198$ & Vernon & 43.702 & -90.5686 & 386 \\
\hline TN14 & Haywood & 35.867 & -89.1586 & 107 & W199 & Walworth & 42.579 & -88.5006 & 286 \\
\hline
\end{tabular}




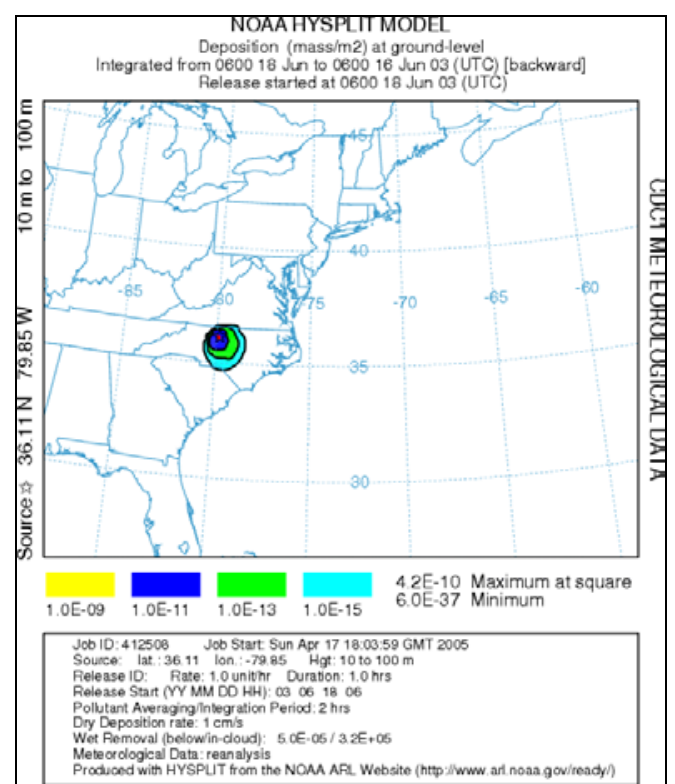

Figure 1.1: HYSPLIT 'backwards' dispersion run from June 18, 2003 
Table 1.3: Emission Factors used

\begin{tabular}{|l|r|}
\hline Source & Emissions Factor \\
\hline \multicolumn{1}{|l|}{$\mathbf{( k g ~ N H}_{\mathbf{3}}$ animal-1 year $\left.\mathbf{- 1}\right)$} \\
\hline Beef Cattle & 10.2 \\
\hline Dairy Cattle & 28.04 \\
\hline Horses & 8 \\
\hline Hogs and Pigs & 16.43 \\
\hline Sows & 6.39 \\
\hline Fattening Pigs & 1.34 \\
\hline Sheep & 0.28 \\
\hline Broilers & \\
\hline Chicken & 0.37 \\
\hline Laying Hens & 0.269 \\
\hline Pullets 13-20 weeks old & 0.17 \\
\hline Pullets <13 weeks old & 0.858 \\
\hline Turkeys &
\end{tabular}

Source: Aneja, 2003 
Table 1.4: Emission Factors used (Fertilizer)

\begin{tabular}{|l|lr|}
\hline Crop & N Fertilizer Rate \\
Alfalfa & (kg N/ha) \\
Barley & 0 \\
Corn & 75 \\
Cotton & 125 \\
Bean & 100 \\
Idle Cropland & 0 \\
Hay & 0 \\
Oats & 25 \\
Pasture & 75 \\
Peanut & 0 \\
Potatoes & 0 \\
Rice & 250 \\
Sorghum & 140 \\
Soybean & 75 \\
Spring Wheat & 0 \\
Sugarbeets & 50 \\
Sugarcane & 150 \\
Sunflower & 200 \\
Tobacco & 100 \\
Vegetables & 100 \\
Winter Wheat & 100 \\
\hline
\end{tabular}

Source: NASS, 2006 
Table 1.5. Annual Ammonia Emissions Flux from Livestock and Fertilizer Sources, 2002.

\begin{tabular}{|c|c|c|}
\hline STATE & $\begin{array}{c}\text { Ammonia Emissions } \\
\left(\mathrm{kg}^{*} 10^{6}\right)\end{array}$ & $\begin{array}{c}\text { Ammonia Flux } \\
\left(\mathrm{kg} / \mathrm{km}^{2 /} \mathrm{yr}\right)\end{array}$ \\
\hline Alabama & 61.371 & 1209.268 \\
\hline Florida & 28.324 & 524.544 \\
\hline Georgia & 80.263 & 1385.793 \\
\hline Kentucky & 45.683 & 1149.790 \\
\hline Mississippi & 59.669 & 1271.881 \\
\hline North Carolina & 142.234 & 2919.565 \\
\hline South Carolina & 35.768 & 1187.882 \\
\hline Tennessee & 70.109 & 1700.891 \\
\hline Southeast & 523.421 & 1417.105 \\
\hline Illinois & 95.073 & 1710.149 \\
\hline Indiana & 77.231 & 2153.062 \\
\hline Iowa & 153.915 & 2754.631 \\
\hline Michigan & 39.738 & 699.502 \\
\hline Minnesota & 142.194 & 1785.981 \\
\hline Missouri & 102.959 & 1494.371 \\
\hline Ohio & 75.805 & 1851.045 \\
\hline Wisconsin & 70.544 & 1298.818 \\
\hline Midwest & 757.458 & 1691.024 \\
\hline
\end{tabular}



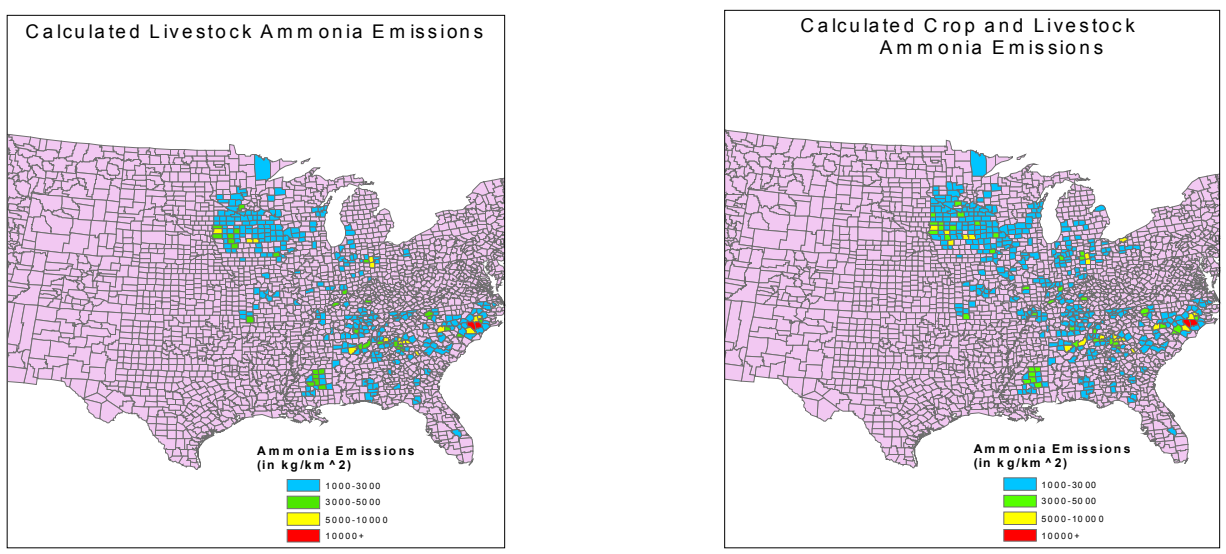

(a)

(b)
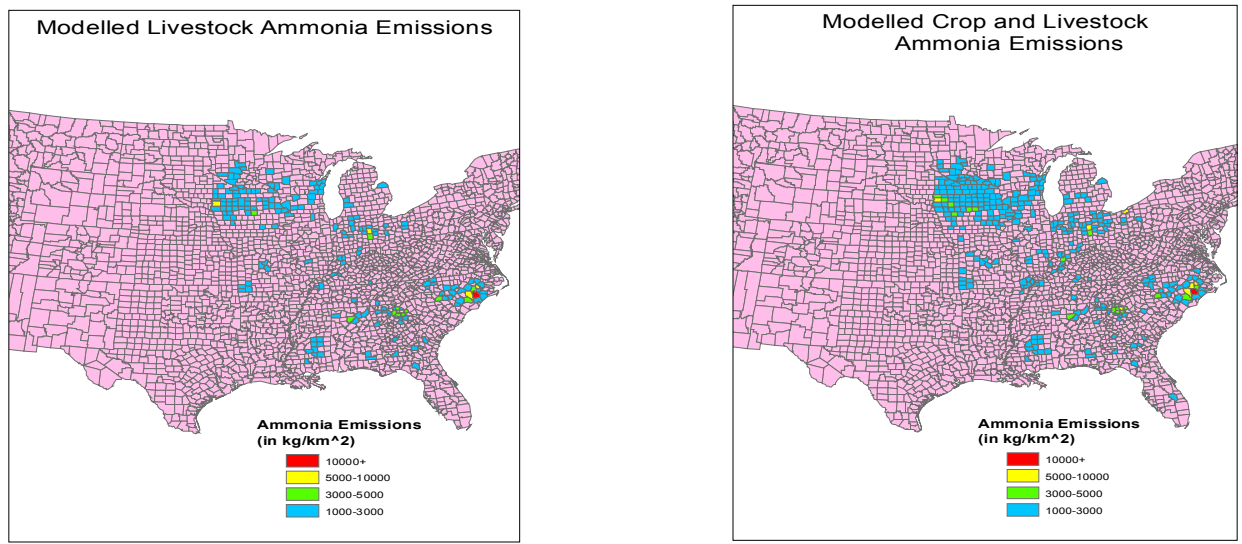

(c)

(d)

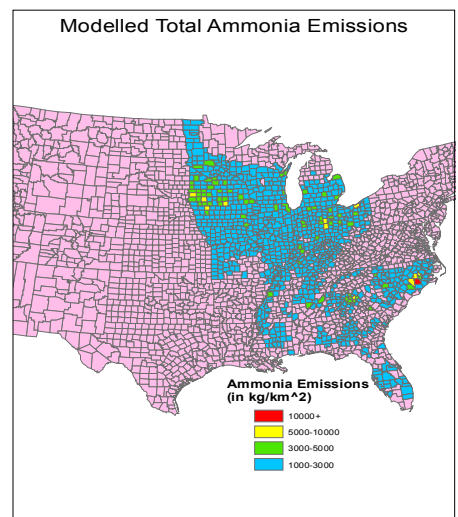

(e)

Figure 1.2. Spatial distribution of $\mathrm{NH}_{3}$ flux $(\mathrm{kg} / \mathrm{sq} . \mathrm{km} /$ year) 
Table 1.6: Ten Counties with Highest Annual Agricultural Emissions

\begin{tabular}{|l|l|l|l|}
\hline SOUTHEAST & $\begin{array}{l}\mathbf{N H}_{\mathbf{3}} \\
\mathbf{( k g / s q} \mathbf{~ k m} / \mathbf{y r})\end{array}$ & MIDWEST & $\begin{array}{l}\mathbf{N H}_{\mathbf{3}} \\
\mathbf{( k g / s q} . \mathbf{k m} / \mathbf{y r})\end{array}$ \\
\hline Duplin County, NC & 24209.41 & Mercer County, OH & 12943.77 \\
\hline Sampson County, NC & 19569.96 & Hardin County, IA & 10689.74 \\
\hline Franklin County, GA & 14858.32 & Hamilton County, IA & 10592.47 \\
\hline Greene County, NC & 13687.89 & Sioux County, IA & 9511.132 \\
\hline Wayne County, NC & 12711.48 & Darke County, OH & 8606.599 \\
\hline Madison County, GA & 10662.38 & Buena Vista County, IA & 7701.534 \\
\hline Kullman County, AL & 10227.02 & Martin County, MN & 6918.426 \\
\hline Habershan County, GA & 10132.06 & Washington County, IA & 6852.765 \\
\hline Banks County, GA & 9813.943 & Carroll County, IA & 6797.724 \\
\hline Union County, NC & 9776.172 & Dubois County, IN & 6268.582 \\
\hline
\end{tabular}


(a)

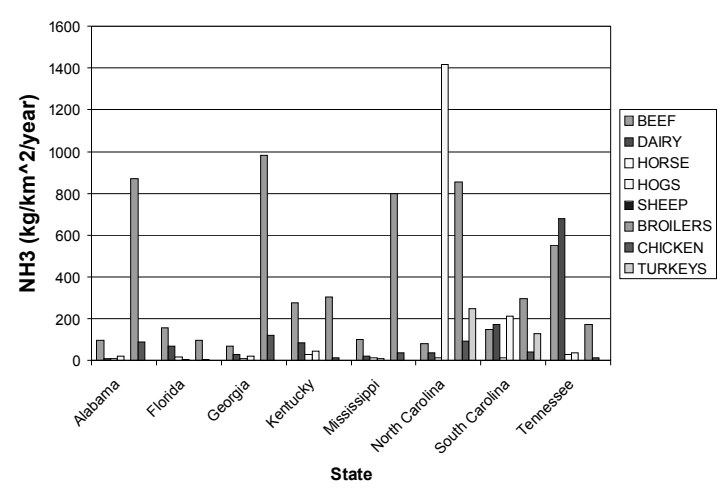

(b)

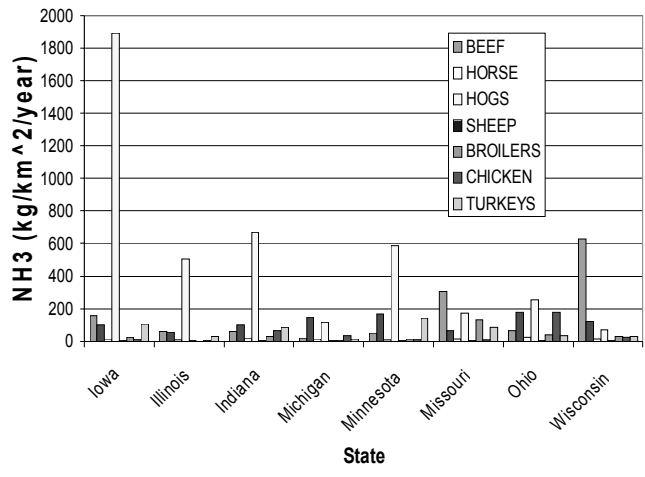

Figure 1.3: Total ammonia emissions from specific agricultural sources, by state 
(a)

\section{Percentage of Ammonia Emissions Contributed to Agricultural Source in Southeastern United States}

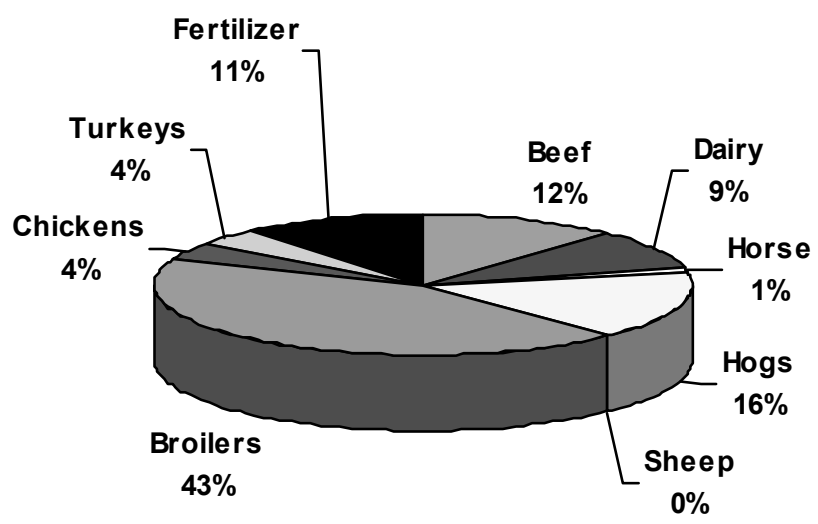

\begin{tabular}{|l|}
\hline Beef \\
$\square$ Dairy \\
$\square$ Horse \\
$\square$ Hogs \\
$\square$ Sheep \\
$\square$ Broilers \\
$\square$ Chickens \\
$\square$ Turkeys \\
$\square$ Fertilizer \\
\hline
\end{tabular}

(b)

\section{Percentage of Ammonia Emissions Contributed to Agricultural Source in Midwestern United States}

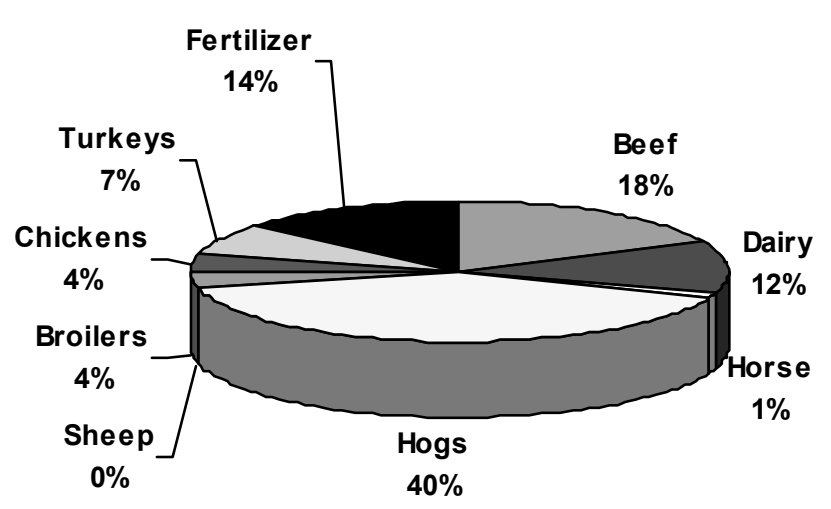

\begin{tabular}{|l|}
\hline Beef \\
$\square$ Dairy \\
$\square$ Horse \\
$\square$ Hogs \\
$\square$ Sheep \\
$\square$ Broilers \\
$\square$ Chickens \\
$\square$ Turkeys \\
$\square$ Fertilizer \\
\hline
\end{tabular}

Figure 1.4: Emissions from specific agricultural sources, by region 


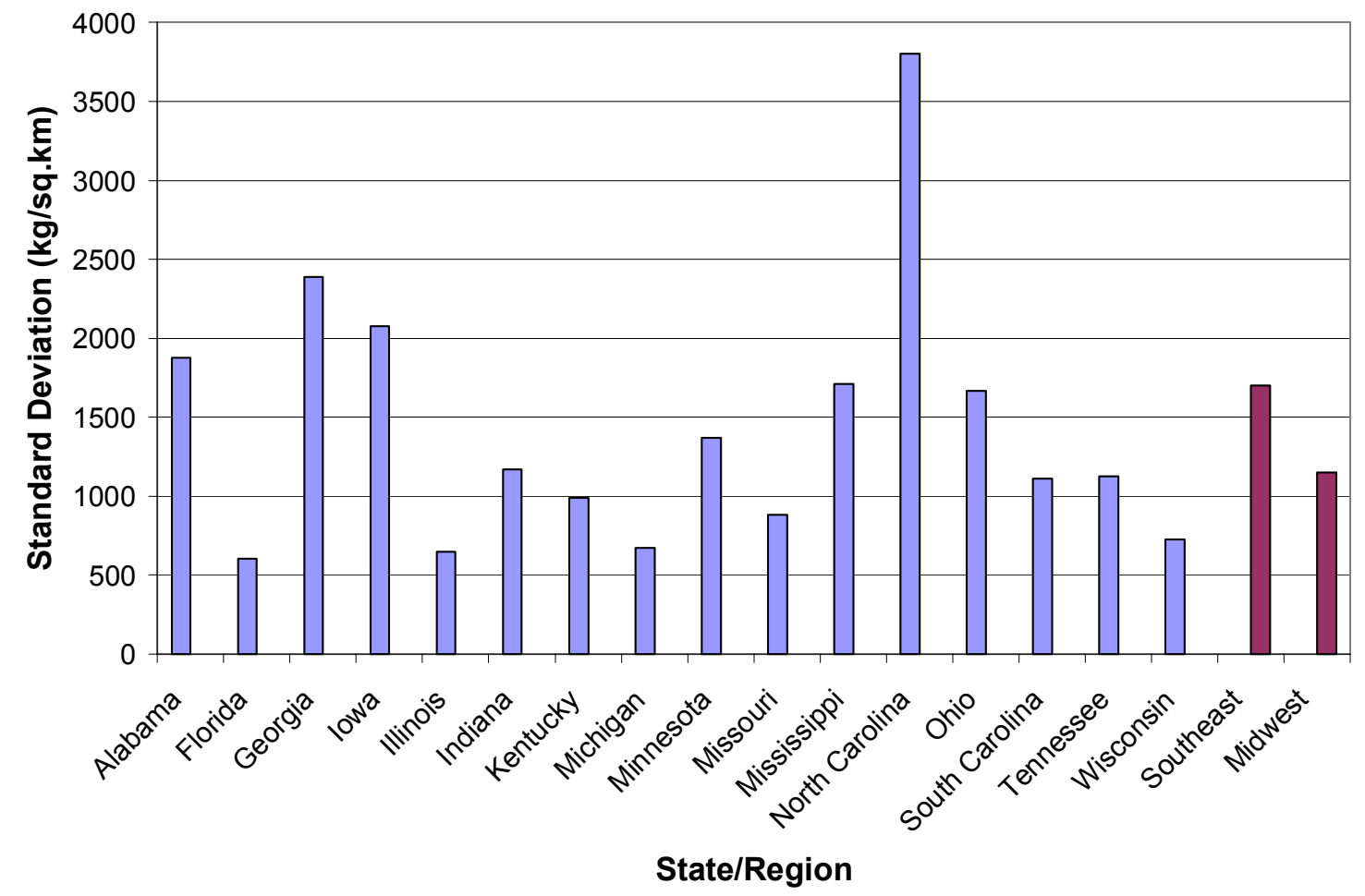

Figure 1.5. Standard deviation of ammonia emissions between counties in specific states. 
(a)

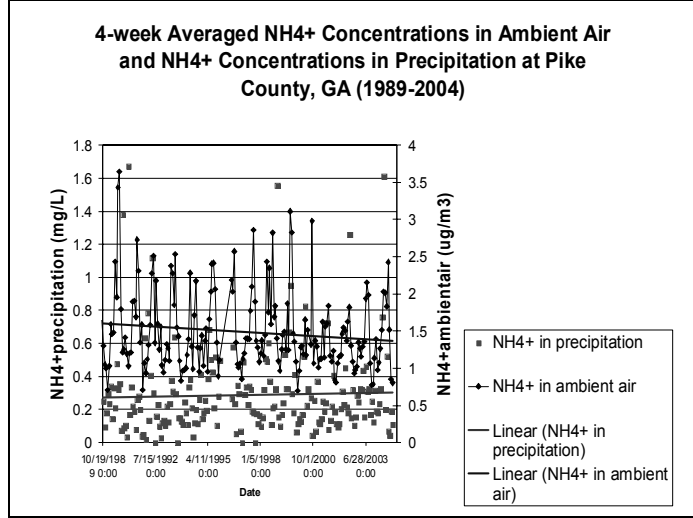

(b)

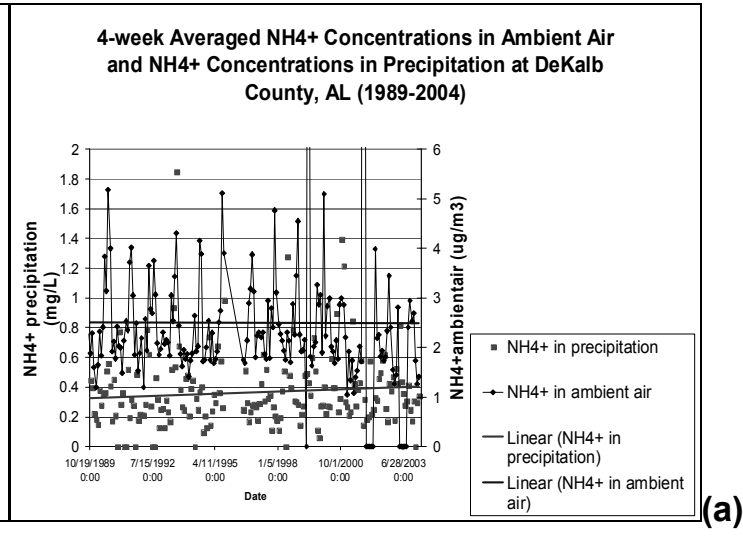

(c)

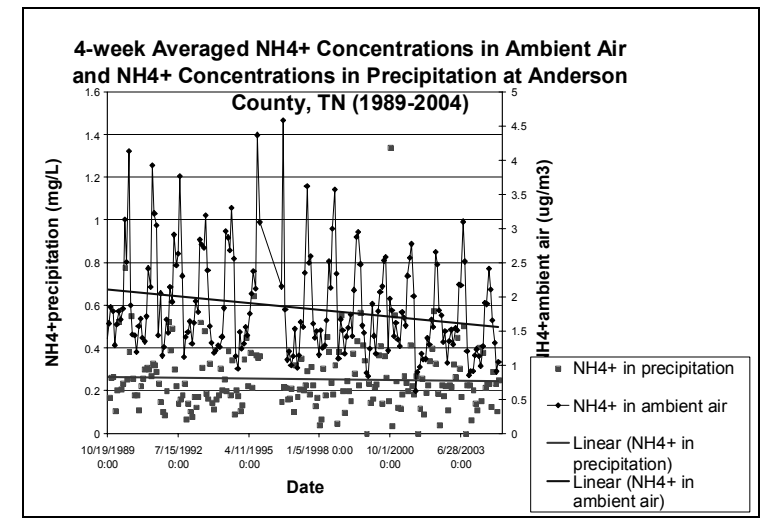

Figure 1.6: Ammonium ion concentrations from 3 Southeast sites 
(a)

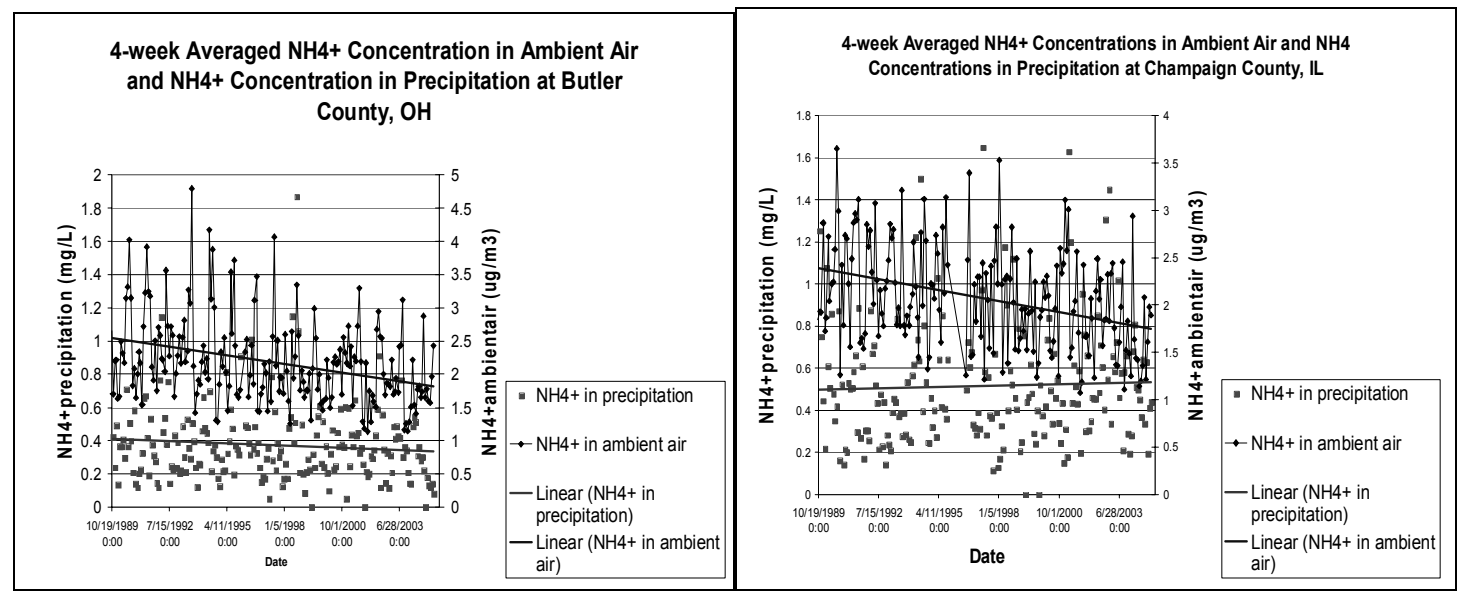

(c)

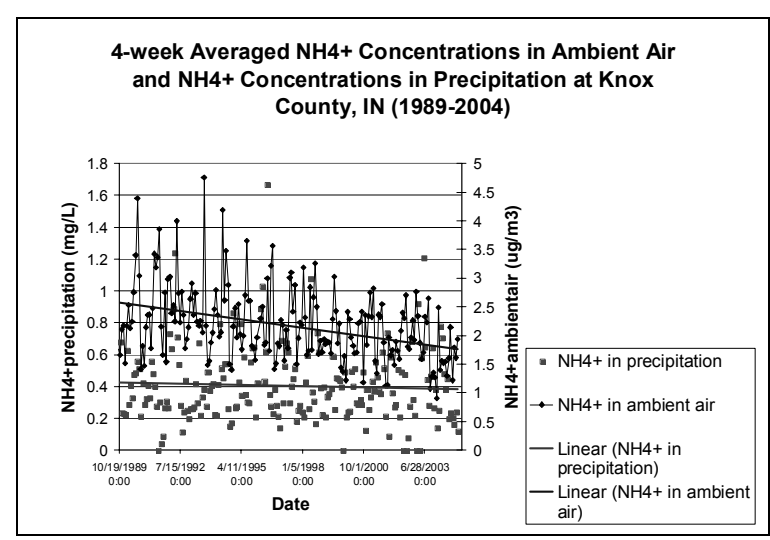

Figure 1.7. Ammonium ion concentrations from 3 Midwest sites 


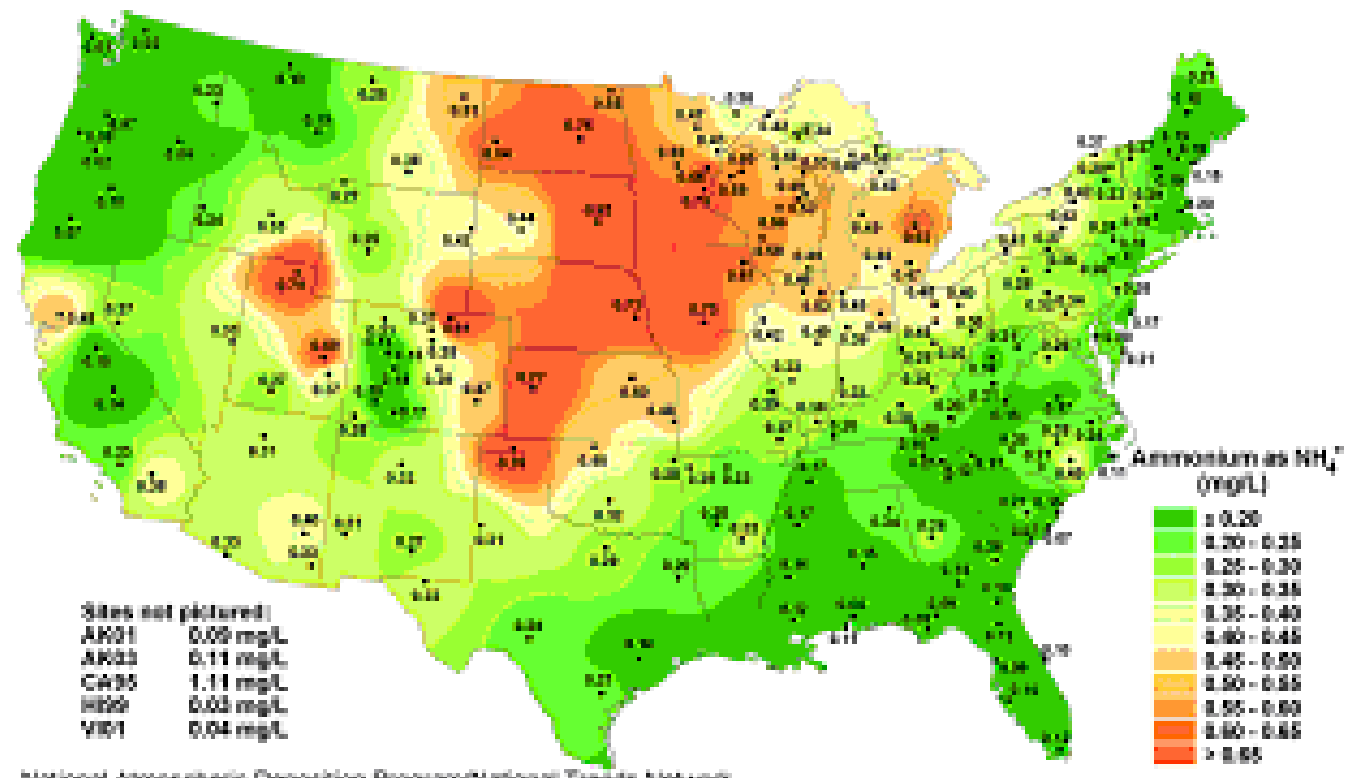

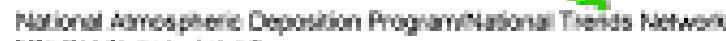

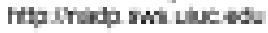

(a)

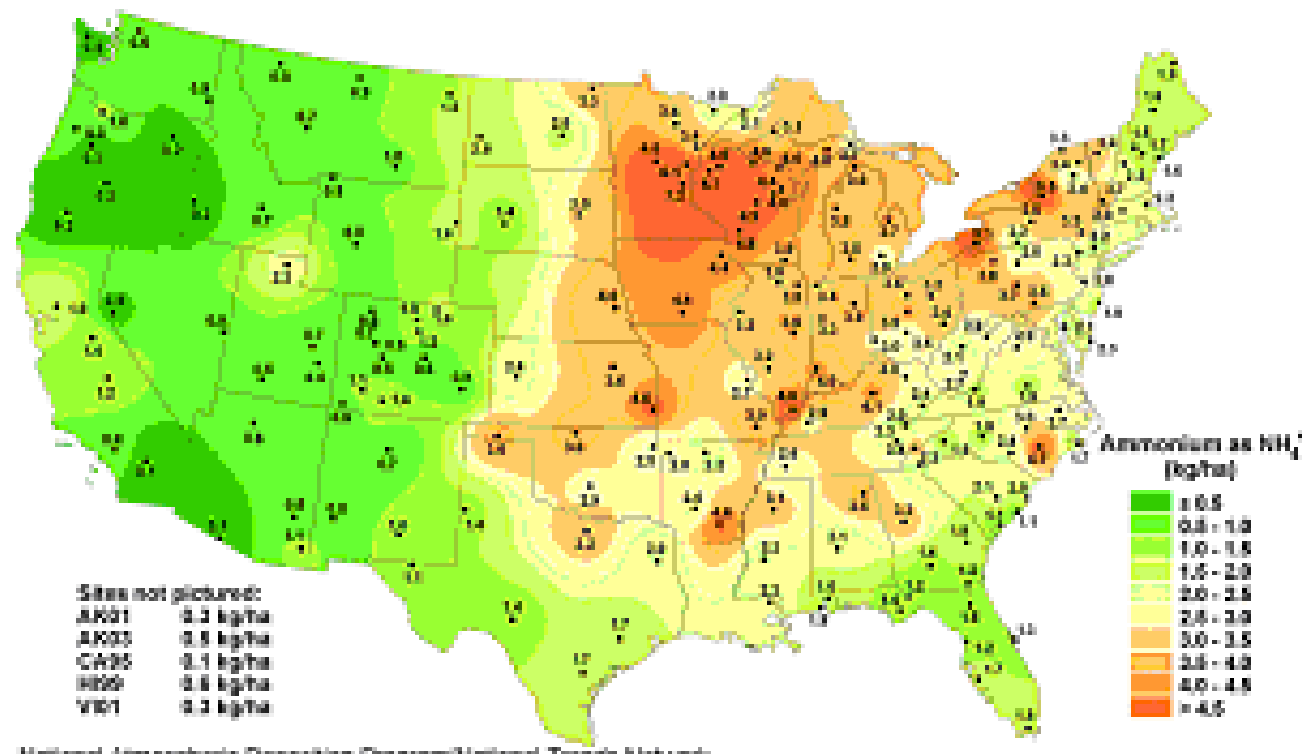

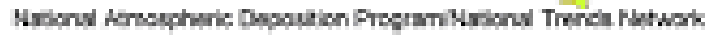

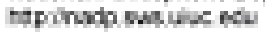

(b)

Figure 1.8. NADP maps for 2002 Ammonium ion concentration (a) and ammonium ion wet deposition (b). [Obtained from NADP/NTN (2005)] 
Table 1.7: Percentages of agricultural ammonia emissions deriving from specific sources in North Carolina

\begin{tabular}{|l|r|}
\hline BEEF & $3 \%$ \\
\hline DAIRY & $1 \%$ \\
\hline HORSE & $0 \%$ \\
\hline HOGS & $47 \%$ \\
\hline SHEEP & $0 \%$ \\
\hline BROILERS & $28 \%$ \\
\hline CHICKEN & $3 \%$ \\
\hline TURKEYS & $7 \%$ \\
\hline FERTILIZER & $10 \%$ \\
\hline
\end{tabular}


Table 1.8: Results of Binomial proportion test for difference in source region air on high and low $\mathrm{NH}_{4}^{+}$concentration days

\begin{tabular}{|l|r|r|r|}
\hline & \multicolumn{1}{|c|}{$\begin{array}{c}\text { 90th percentile } \\
\text { concentration Days }\end{array}$} & $\begin{array}{c}\text { 10th percentile } \\
\text { concentration Days }\end{array}$ & P-value \\
\hline Rowan & 17 & 10 & 0.1747 \\
\hline Wake & 22 & 12 & 0.0241 \\
\hline
\end{tabular}


(a)

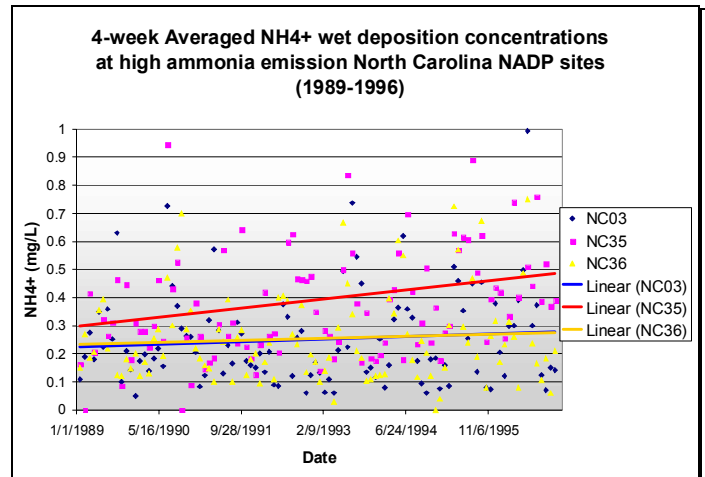

(c)

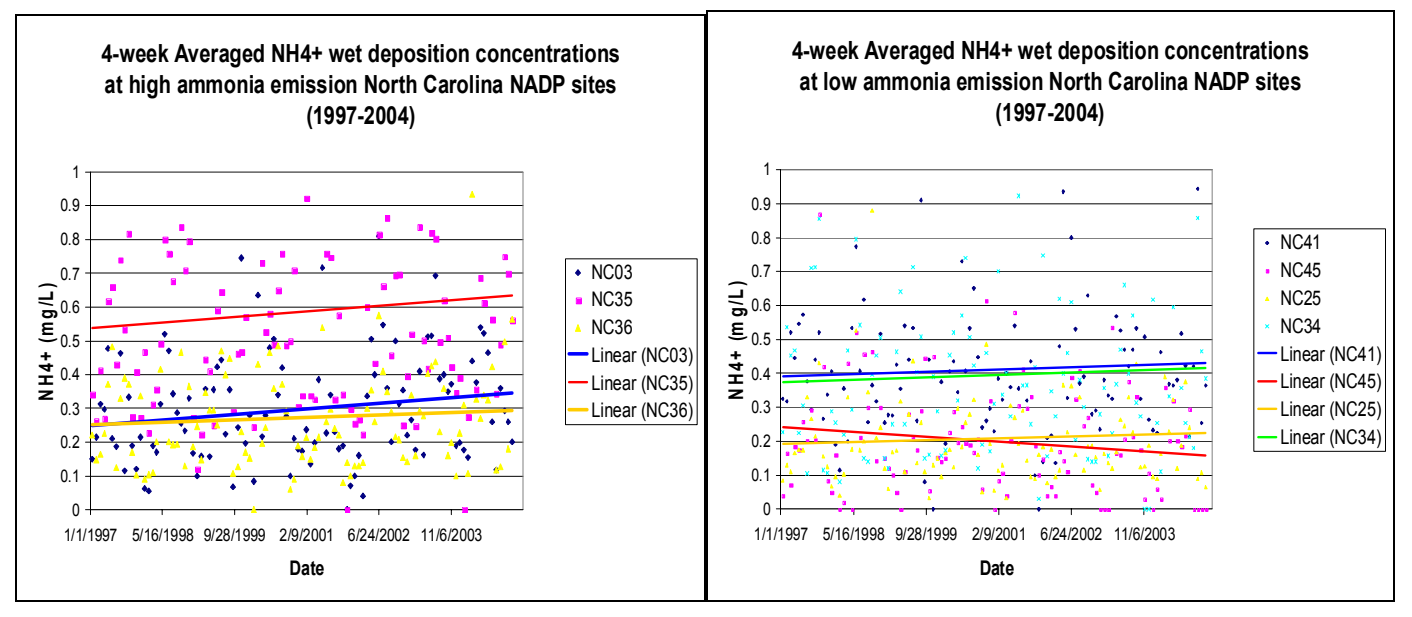

(b)

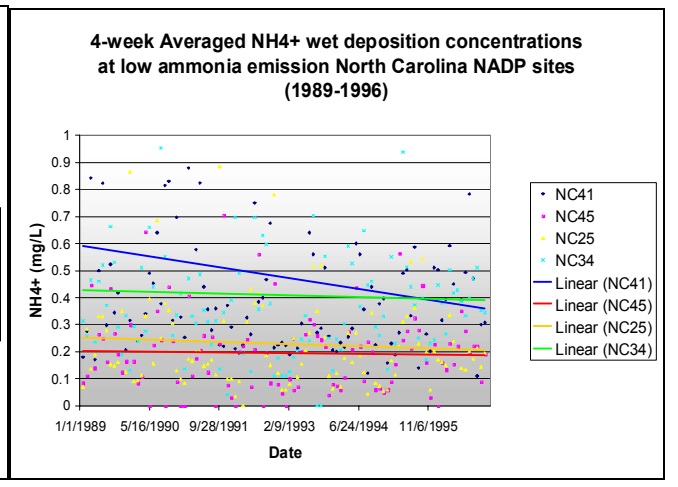

(d)

Figure 1.9: $\mathrm{NH}_{4}{ }^{+}$wet deposition concentrations and trends over North Carolina, from 1989-

2004. 
2. Analysis of local and regional effects of governmental environmental policy through observations in precipitation chemistry and local ambient concentration 


\subsection{Introduction}

Over the past 35 years, local, regional, and federal governments have been increasing aware of and concerned by the effects of air pollution on the environment, economy, and health of its citizens. Numerous measures have been laid out to attempt to curb the effects of various pollutants by limited their emissions. Two such measures are the 1990 Clean Air Act Amendments instated by the U.S. Federal Government and the 1997 Swine Confinement Facility Moratorium. The 1990 Clean Air Amendments were designed to combat acid rain, urban air pollution, and toxic emissions. This study examined the trends in ambient concentrations of 2 key pollutants, sulfur dioxide and nitrate, from various locations in North Carolina to see if effects from the institution of these amendments had led to a change in the emissions trends. NOx is derived from from a variety of anthropogenic sources, especially motor vehicles (55\%), utilities (22\%), and commercial, residential, and industrial sources (22\%) (U.S. EPA, 2006). The highly reactive gas is generally colorless and odorless, but can produce a reddish-brown haze over urban centers when it combines with PM (U.S. EPA, 2006). It is a major culprit in the formation of ozone and acid rain and can contribute to nutrient overload and visibility impairment. In addition to respiratory effects caused by its reaction with ozone, it is a key greenhouse gas. The goals of the Clean Air Act amendment and subsequent amendments propose to reduce NOx emissions from cars, vans, pickups, and SUVs by at least $77 \%$ by 2009 , and cut emissions from diesel vehicles (trucks and buses) by at least 90\%) (U.S. EPA, 2006). The 1990 Amendments' goal to reduce electrical utility emission by 2 million tons per year has already been reached as of 2000 (U.S. EPA, 2006). In addition, since NOx is able to travel great distances, a NOx transport regulation has been implemented for 21 Eastern U.S. states, including North Carolina and 
surrounding states, which requires states to develop plans to curb NOx emissions that may affect the broader region (U.S. EPA, 2006). Sulfur Dioxide is a soluable compound that comes generally from fossil fuel combustion. Because of this, some $65 \%$ of $\mathrm{SO}_{2}$ emissions stem from power plant utilities (U.S. EPA, 2006). Additional, 18\% derives from fuel combustions from industrial sources and another $5 \%$ is derived from vehicular engines (U.S. EPA, 2006). Sulfur dioxide is an extremely unhealthy pollutant and can lead to lung and respiratory problems as well as heart disease. In addition, even short peaks in concentration can cause asthma sufferers to endure attacks. $\mathrm{SO}_{2}$ is also a key critera of acid rain and leads to reduced visibility, which is of exceptional concern in Western North Carolina's Smoky Mountains. EPA guidelines have are to reduce $\mathrm{SO}_{2}$ emissions from power plants by up to $50 \%$ in 2010 (U.S. EPA, 2006). Success has occurred by install pollution control equipment at power plants, reducing emissions during industrial processing, limiting the sulfur content of burned fuels, and using cleaner fuels such as natural gas.

In Early 1997, a moratorium was put into effect by the North Carolina General Assembly, to cap the number and size of hog-confinement facilities in the state to that exist at the time of enactment. The General Assembly was reacting to the hog operations detrimental effect on the environment, in terms of water pollution, odor, disease, and air pollution. The moratorium banned the creation of any new confinement facilities in the state, effectively eliminating the growth of the swine population in the state. One of the key air pollution problems associated with the hog facilities are the ammonia emissions. The facilities, particularly in the southeastern part of North Carolina have been allegedly responsible for enhanced ammonium ion concentrations throughout eastern parts of the 
state. Given the effect the moratorium has had on stopping the rapid growth of the industry in North Carolina, it is of interest to examine whether there has been a reduction, or at least halting of the increase, in ammonium ion concentrations in the area relative to the years before the moratorium was in place. This study looked at pre-1997 trends in ammonium ion concentrations and compared them to post-moratorium trends.

\section{Methods}

The four North Carolina CastNet sites were used to study the overall trends in $\mathrm{SO}_{2}$ and $\mathrm{NO}_{3}$ concentrations both before and after the 1990 Clean Air Act Amendments. From the period 1994-2005, Beaufort, NC, BFT 142, located along the eastern coast is an example of a marine environment site. Candor, NC, CND125, had data from 1990-2005 from the central Sandhills portion of the state, located near Pinehurst. Cowetta, NC, COW137, (1988-2005) is located along the Georgia Border just to the south of the Smoky Mountains, a key region of visibility degradation concern. Finally, Cranberry, NC, PNF (1989-2005) is located along the border of Tennessee in the heart of the Appalachians. Yearly averaged $\mathrm{SO}_{2}$ and $\mathrm{NO}_{3}$ concentrations were obtained for each of these sites.

In order to analyze the effects of the swine moratorium, the concentrations of ammonium ions in precipitation were analyzed from six NADP sites in North Carolina from 1989-1996 and again from 1997-2004. Four of the sites are considered low agricultural emissions locations. NC25 is located in Macon County, in the far western part of the state. Also in the west, but north of NC 25 in a higher terrain, is NC45, in Yancey County (elevation 1,987 m). Further to the east, sandwiched between the Greensboro-Winston-Salem and Charlotte metropolitan areas, lies Rowan County 
(NC34). The final low-emissions site was Wake County, where the capital of Raleigh is located. The three high emissions sites, NC03, NC35, and NC36, are located in the eastern half of the state. NC36 is located in Scotland County, in the south-central part of the state and NC03, in Bertie County, in the low-lying northeastern section of the state,. Finally, there is Sampson County, in the heart of the hog production region in North Carolina in the southeastern part of the state.

Data was from the various sites was plotted using Microsoft Excel, trend lines were developed and averaged values were also obtained.

\subsection{Results}

Figure 2.1 shows the results from BFT142. $\mathrm{SO}_{2}$ concentrations in ambient air have been increasing over the last decade, rising from $2.8 \mathrm{mg} / \mathrm{m}^{3}$ in 1994 to $3.4 \mathrm{mg} / \mathrm{m}^{3}$ in 2005 . Contrastingly, $\mathrm{NO}_{3}$ levels have remained relatively stable at around $1.25 \mathrm{mg} / \mathrm{m}^{3}$. Although this dataset began after the Clean Air Act of 1990 was implemented, it is still interesting to note the significant increase. Figure 2.2 shows the annual averages for the two pollutants in CND125. Here, the data shows a downward trend in $\mathrm{SO}_{2}$ concentrations, which are as a whole significantly higher $\left(4.8 \mathrm{mg} / \mathrm{m}^{3}\right.$ to $\left.3.0 \mathrm{mg} / \mathrm{m}^{3}\right)$ than those totals from the coastal location. Again, $\mathrm{NO}_{3}$ levels remain at a near constant 0.8 $m \mathrm{~g} / \mathrm{m}^{3}$. This site began recording observations in 1990 , and the downward trend is evident for the period following the Act's implementation. Next, Figure 2.3 shows annual concentrations of $\mathrm{SO}_{2}$ and $\mathrm{NO}_{3}$ for $\mathrm{COW} 137$ which again present a downward trend for sulfur dioxide concentrations throughout the period of observation, both before and after 1990, so it is unclear the extent of the effect of the 1990 Act's direct influence.

Nonetheless, $\mathrm{SO}_{2}$ levels remained before 1990 had levels dropping from $2.3 \mathrm{mg} / \mathrm{m}^{3}$ while 
averages after that period dropped from around $1.5 \mathrm{mg} / \mathrm{m}^{3}$. As in the other two sites, $\mathrm{NO}_{3}$ levels are steady, in this case around $0.1 \mathrm{mg} / \mathrm{m}^{3}$. Finally, at PNF126, shown it Figure 2.4, pre-Clean Air Act levels of $\mathrm{SO}_{2}$ are around $4 \mathrm{mg} / \mathrm{m}^{3}$ whereas after 1990, levels decrease to around $3.1 \mathrm{mg} / \mathrm{m}^{3}$ and continue decreasing. These higher levels of $\mathrm{SO}_{2}$ are likely regionally transported from power plants associated with the Tennessee Valley Authority, which has been the focus of political and environmental debates between North Carolina and it neighbors. Once again, levels of $\mathrm{NO}_{3}$ remain stable.

Overall, the sites' sulfur dioxide trends show the effect of Federal and State environmental policies in general, but with limited data before 1990 and a seemingly downward trend in $\mathrm{SO}_{2}$ concentrations before the $1990 \mathrm{Act}$, it is uncertain as to what effect the 1990 Clean Air Act Amendment has had directly. $\mathrm{NO}_{3}$ shows no overall trend, so no conclusions can be brought from this study regarding the effectiveness of EPA effects to curb nitrate.

Figure 2.5 shows the weekly ammonium ion concentrations (a 4-week rolling average) in wet deposition at each of the six sites. As expected, Sampson County (NC35) has higher wet deposition values over both periods than the other high-emission sites. However, Wake County (NC41) and Rowan County (NC34) have generally high average wet deposition values than the other two high emission sites. For Wake County this feature can easily be explained by its proximity to high emissions areas, but for NC34, the reason for the high levels is more uncertain. As for the trends, the hog moratorium has clearly cut down on the rate of increase of $\mathrm{NH}_{4}{ }^{+}$concentrations in precipitation over Sampson County (NC35),, whose rate of increase over the 8 year period before the moratorium was $9 \%$, and since the moratorium is $4 \%$. The other sites show much less of 
an effect. Bertie County (NC03) and Scotland County (NC36) have steady but slow increase in $\mathrm{NH}_{4}{ }^{+}$concentration in precipitation from 1989-2004. For the lower emission sites, Wake County (NC41) saw a significant decrease in concentrations before the moratorium took into effect, with steady levels since then. The urbanization of Wake County over the last 15 years may be a reason for the interesting trends, and this could also explain the enhanced levels over suburban Wake County (NC41). The other two low-emission sites, Macon County (NC25) and Rowan County (NC34), have been generally stable. It is worth noting that $\mathrm{NC45}$ has had a slight increasing trend before the moratorium, with a slight decreasing trend afterwards, whereas NC35 has had the opposite trends.

\subsection{Conclusion}

The effects of the 1990 Clean Air Act are possibly seen in ambient air chemistry over the state of North Carolina when observing trends in Sulfur dioxide. However, limited data before 1990 and a downward trend in the data that is available before 1990 suggests that decrease in concentrations after 1990 may not be direct effects of the 1990 Act. In addition, levels of $\mathrm{NO}_{3}$ over the state have remained nearly constant through the period 1990-2005 and this leads to no conclusive evidence of an effect of the act on nitrate concentrations in ambient air. The effects of the hog moratorium in North Carolina, which undoubtedly curbed the increasing rates of agricultural ammonia emissions in addition to its intended effect of stopping the growth of the hog industry, aren't seen clearly in merely analyzing the trends of ammonium ion concentrations in precipitation over the last seven years, with the exception of areas immediately in the vicinity of the high hog facility density. There are a number of reasons that could be postulated as to why the level of $\mathrm{NH}_{4}{ }^{+}$has not leveled off in the last 7 years since the 
installation of the moratorium, but as with the $\mathrm{NH}_{3}$ emissions, meteorological parameters and industrial activity would need to be taken into account before a more clear understanding of the effect of the moratorium on ammonia emissions is obtained.

\subsection{References}

Clean Air Status and Trends Network (CASTNet), 2003 Annual Report, 2003. (Available as www.epa.gov/acidrain/castnet/annual03/annual03.html).

NADP/NTN, National Atmospheric Deposition Program (NRSP-3)/National Trends Network (August, 2005), NADP/NTN Coord. Off., Illinois State Water Survey, 2204 Griffith Drive, Champaign, IL, 2005 (Available as nadp.sws.uiuc.edu/).

U.S. Environmental Protection Agency. Six Common Air Pollutants. March 2, 2006. (Available online at http://www.epa.gov/air/urbanair/6poll.html). 
Annual Sufur Dioxide and Nitrate Concentrations - Beaufort, NC BFT142 1994-2005

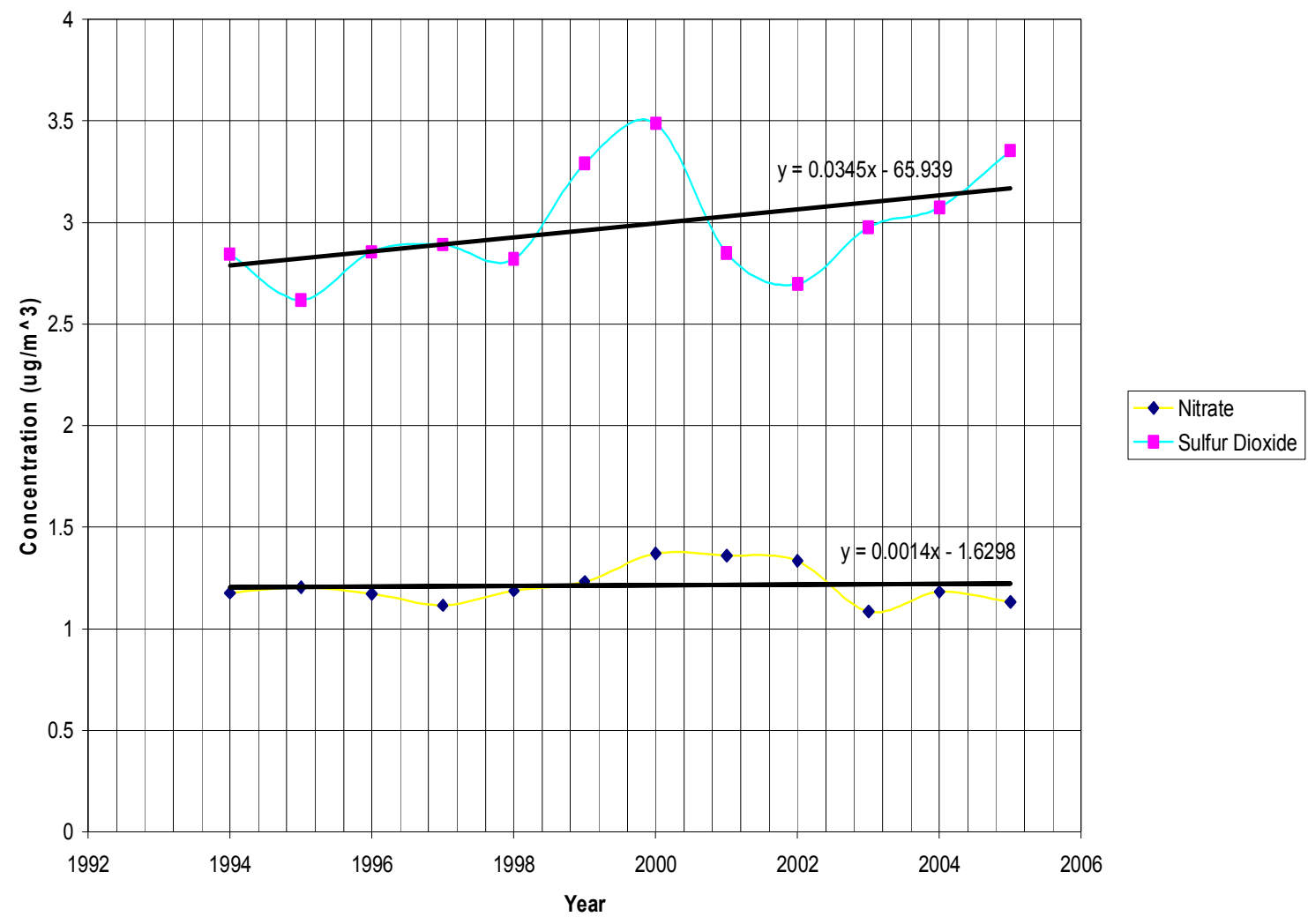

Figure 2.1: Annual $\mathrm{SO}_{2}$ and $\mathrm{NO}_{3}$ Concentrations, Beaufort, NC, from 1994-2005. 
Annual Nitrate and Sulfur Dioxide Concentrations - Candor, NC 1990-2005
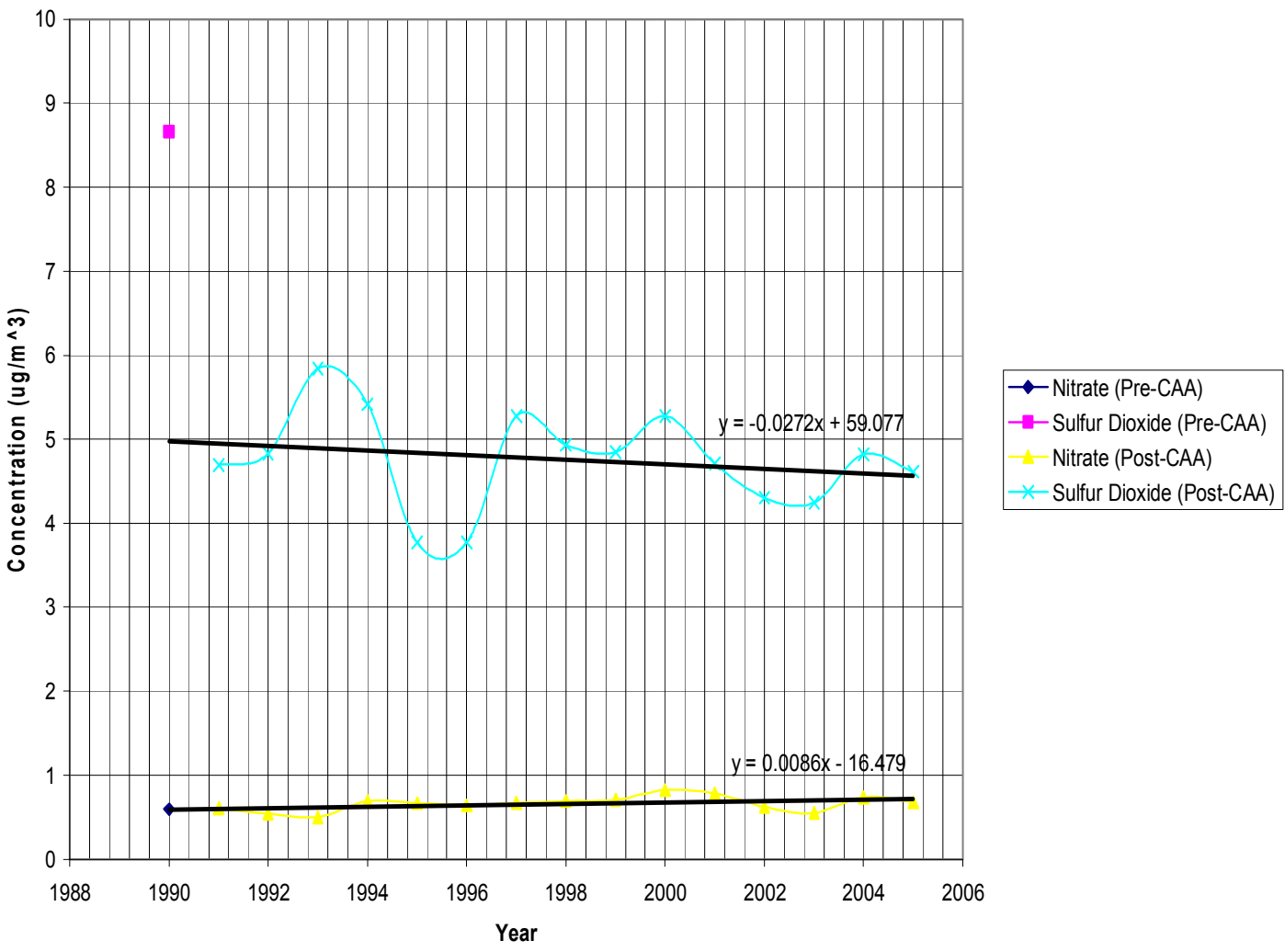

Figure 2.2: Annual $\mathrm{SO}_{2}$ and $\mathrm{NO}_{3}$ Concentrations, Candor, $\mathrm{NC}, 1990-2005$. 
Annual Nitrate and Sulfur Dioxide Concentrations - Cowetta, NC COW137 1988-2005

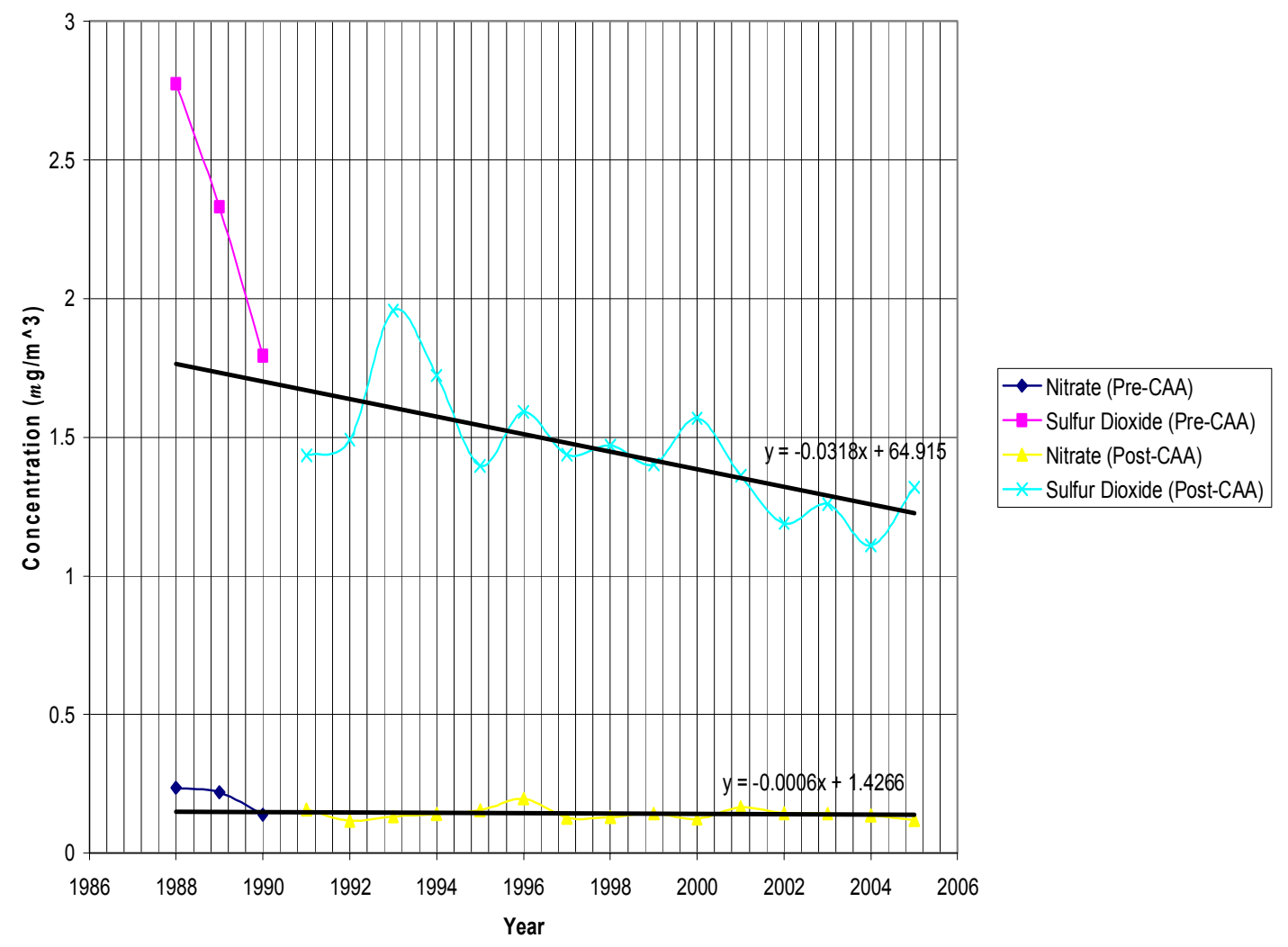

Figure 2.3: Annual $\mathrm{SO}_{2}$ and $\mathrm{NO}_{3}$ Concentrations, Cowetta, $\mathrm{NC}$ 1988-2005. 
Annual Nitrate and Sulfur Dioxide Concentrations Cranberry, NC - PNF126 (1989-2005)

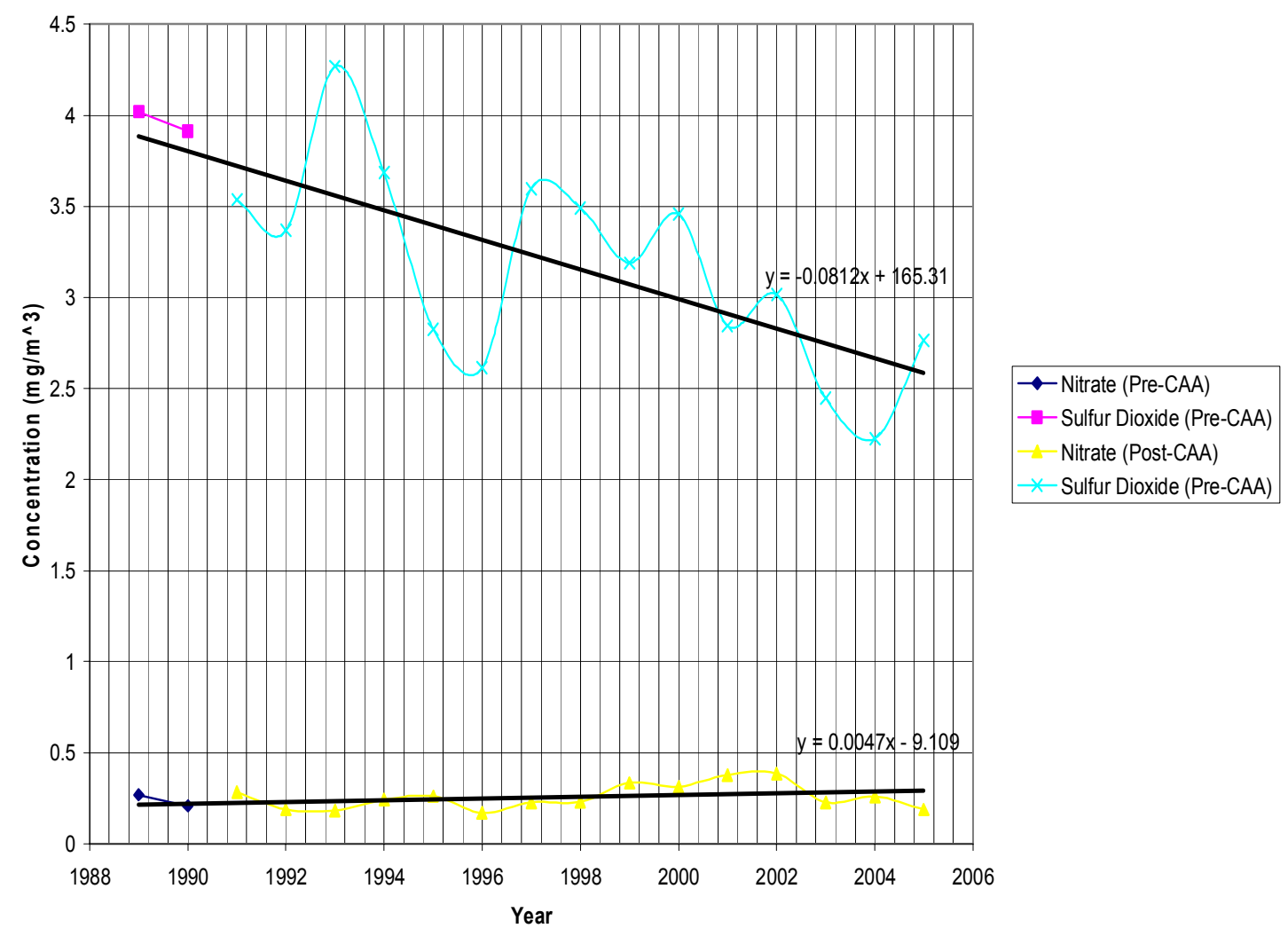

Figure 2.4: Annual $\mathrm{SO}_{2}$ and $\mathrm{NO}_{3}$ Concentrations, Cranberry, $\mathrm{NC}$ 1989-2005. 


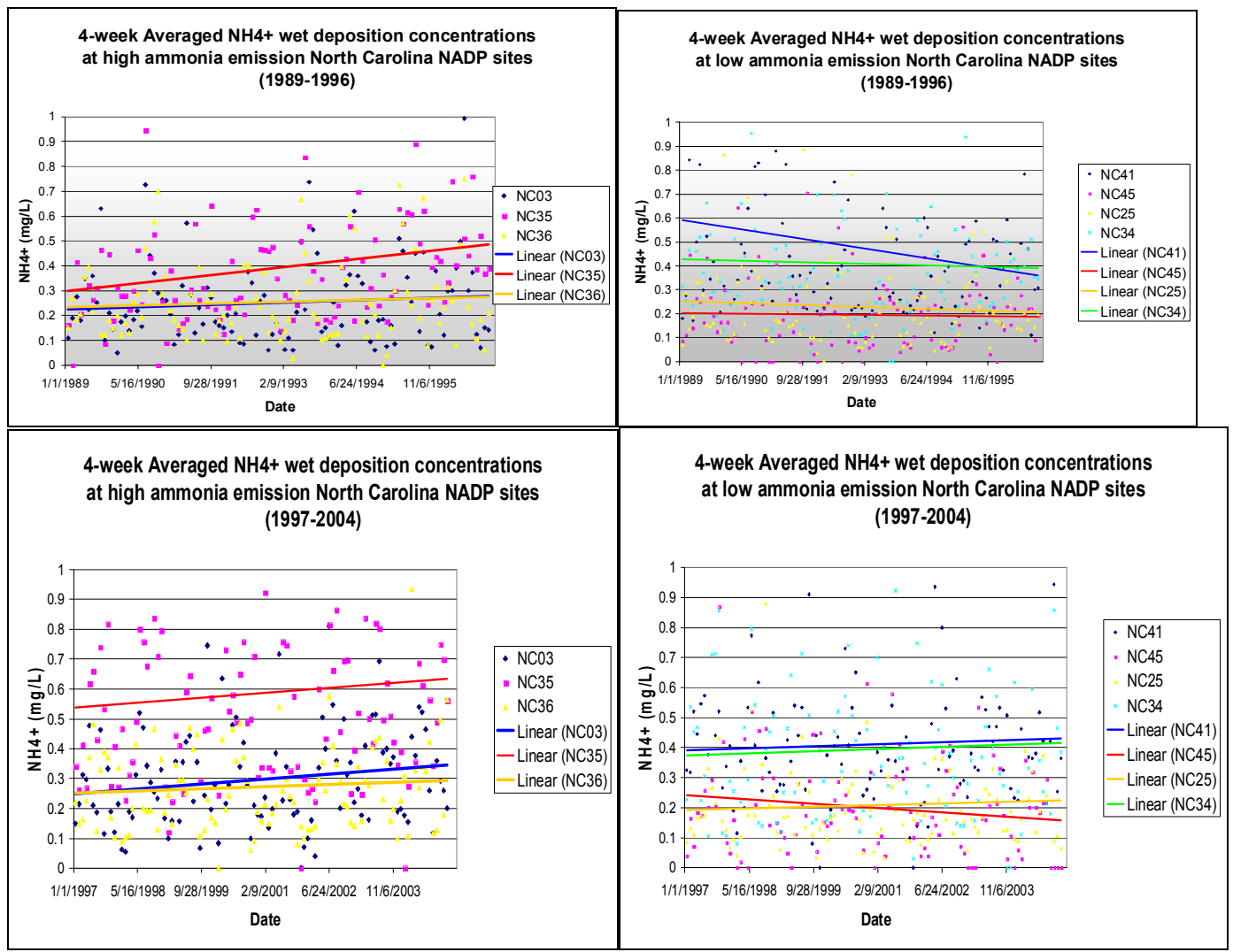

Figure 2.5: $\mathrm{NH}_{4}^{+}$wet deposition concentrations and trends over North Carolina, from 19892004. 
3. APPENDIX 


\title{
3.1 ABSTRACTS
}

\section{Trends in agricultural ammonia emissions and ammonium concentrations in precipitation over the Southeast and Midwest United States}

\author{
Konarik, Stephen and Viney P. Aneja* \\ Department of Marine, Earth, and Atmospheric Sciences \\ North Carolina State University \\ Raleigh, NC 27695-8208 \\ *Corresponding Author: e-mail: viney aneja@ncsu.edu \\ phone: (919)515-7808
}

\begin{abstract}
Emissions from agricultural activities, both crop and animal, are known to contain gaseous ammonia $\left(\mathrm{NH}_{3}\right)$ which through chemical reaction in rainwater changes into ammonium ion $\left(\mathrm{NH}_{4}{ }^{+}\right)$. Using wet deposition data of ammonium from several National Atmospheric Deposition Program/National Trends Network (NADP/NTN) and Clean Air Status Trends Network (CASTNet) sites as well as calculated ammonia emissions from North Carolina and the Southeast and Midwest regions of the United States, trends in ammonium concentrations in precipitation were analyzed for the period of 1983-2004. The beginning of 1997 coincides with the implementation of a swine population moratorium in the state of North Carolina. Results from the analysis in North Carolina indicate a lessening in the rate of increases in $\mathrm{NH}_{4}^{+}$concentration in precipitation since the moratorium went into effect. Sampson County, NC, saw stable ammonium ion concentrations from 1983-1989, an average rise of 9.5\% from 1989-1996, and an average increase of only 4\% from 1997-2004. In addition, HYSPLIT back-trajectory model was used to determine that when ambient air in downwind sites arrived from the high ammonia emissions source region, ammonium concentrations in precipitation were enhanced. For the Southeast United States domain, analysis shows that $\mathrm{NH}_{4}{ }^{+}$concentrations generally increased with increasing $\mathrm{NH}_{3}$ emissions from within the same region. Similar analysis has been performed over the Midwest United States and compared to the results from the Southeast United States. Emissions from the Midwest are attributed to larger animals, including hogs and cattle, whereas the Southeast has a higher percentage of emissions coming from smaller livestock, such as chickens. In addition, the states of the Midwest United States have a much more uniform spatial distribution of emissions.
\end{abstract}

Keywords: Ammonia emissions, North Carolina hog moratorium, ammonium wet deposition 


\title{
Agricultural Ammonia Emissions and the National Atmospheric Deposition Network
}

\author{
Aneja, Viney P. ${ }^{1 *}$, S. Konarik ${ }^{1}$, J, Blunden ${ }^{1}$, R. Knighton ${ }^{2}$ \\ ${ }^{1}$ Department of Marine, Earth, and Atmospheric Sciences \\ North Carolina State University \\ Raleigh, NC 27695-8208 \\ ${ }^{2}$ CSREES, U.S. Department of Agriculture \\ Washington, DC 20024
}

\begin{abstract}
The conversion of ammonia gas $\left(\mathrm{NH}_{3}\right)$ into ammonium ion $\left(\mathrm{NH}_{4}{ }^{+}\right)$is a fundamental process that is of great environmental significance. Excessive amounts of $\mathrm{NH}_{4}{ }^{+}$can lead to acidification of soils and other pollution problems. An agricultural ammonia emissions inventory for the Midwest United States and Southeast United States was developed using data from the United States Department of Agriculture 2002 Census. This inventory indicates total annual ammonia emissions to be nearly the same over the two regions, with $1417.105 \times 10^{6} \mathrm{~kg} \mathrm{NH}_{3} / \mathrm{km} /$ year over the Southeastern United States with $1691.024 \times 10^{6} \mathrm{~kg} \mathrm{NH}_{3} / \mathrm{km} /$ year over the Midwestern United States. The flux rates are similar to those of model simulations from the Carnegie Mellon University Ammonia Model. Comparing these flux rates to the ammonium ion concentration and wet deposition obtained from the National Atmospheric Deposition Program (NADP) monitoring network reveals discrepancies from the results projected by the emissions inventory. The NADP network shows deposition values of ammonium at nearly twice the concentration of the Midwest U.S. as in the Southeast U.S. These contrasts have been explored and reasons for the differences are discussed.
\end{abstract}

